\title{
Understanding Firms' Inflation Expectations Using the Bank of Canada's Business Outlook Survey
}

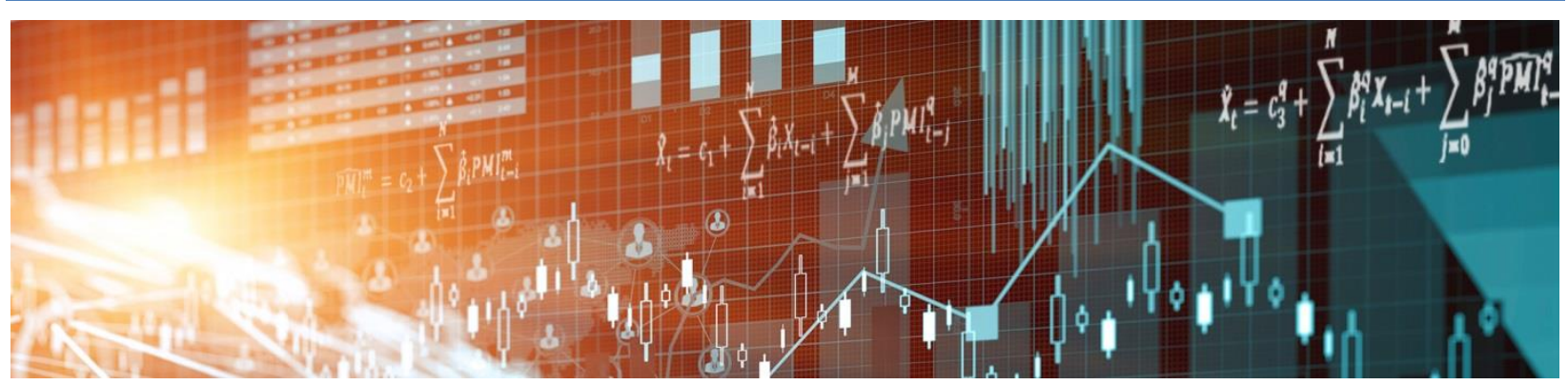

by Simon Richards and Matthieu Verstraete 
Bank of Canada Staff Working Paper 2016-7

February 2016

\title{
Understanding Firms' Inflation Expectations Using the Bank of Canada's Business Outlook Survey
}

by

\section{Simon Richards and Matthieu Verstraete}

\author{
Canadian Economic Analysis Department \\ Bank of Canada \\ Ottawa, Ontario, Canada K1A 0G9 \\ mverstraete@bankofcanada.ca \\ simon.richards@parl.gc.ca
}

This paper was written while Simon Richards was a staff member of the Bank of Canada. He currently works for the Library of Parliament. 


\section{Acknowledgements}

We would like to thank Michael Ehrmann, Lise Pichette, Laurent Martin and Lena Suchanek for useful comments, as well as David Dupuis, a former Bank of Canada employee, who had done some analysis from which this paper benefited. We also thank participants at the 6th CESifo conference on Macroeconomics and Survey Data, the 6th Annual International Conference on Central Bank Business Surveys, the 2015 Canadian Economics Association conference in Toronto, the 2015 Société canadienne de science économique in Montréal, the Bank of Canada's Visiting Scholar Program and an internal seminar for helpful comments. All errors and omissions are our own. 


\begin{abstract}
Inflation expectations are a key determinant of actual and future inflation and thus matter for the conduct of monetary policy. We study how firms form their inflation expectations using quarterly firm-level data from the Bank of Canada's Business Outlook Survey, spanning the 2001 to 2015 period. The data are aggregated to construct an inflation expectations index. Results based on the index suggest that expectations are not consistent with the rationality assumption but are, still, more complex than purely adaptive expectations. Firms' own unique experiences, such as the dynamics of the prices they expect to pay (wages/inputs), significantly influence aggregate expectations. Expectations are also found to be significantly and positively correlated with movements in oil prices. Most of the preceding results hold at the firm level. The estimation of structural shift specifications suggests that inflation expectations in Canada have drifted downward since the Great Recession. However, the data do not suggest that Canadian businesses' expectations have become unanchored.
\end{abstract}

JEL classification: C1, C2, C25, D21, D84, E31, E52, E58

Bank classification: Credibility; Central bank research; Econometric and statistical methods; Firm dynamics; Inflation targets; Inflation and prices; Monetary policy framework

\title{
Résumé
}

Les anticipations d'inflation constituent un déterminant essentiel de l'inflation actuelle et future et entrent par conséquent en ligne de compte dans la conduite de la politique monétaire. À partir des données trimestrielles recueillies par la Banque du Canada auprès des firmes dans le cadre de son enquête sur les perspectives des entreprises, de 2001 à 2015, les auteurs examinent la façon dont les firmes forment ces anticipations. Les données sont agrégées pour établir un indice des anticipations d'inflation. Les résultats fondés sur cet indice montrent que les anticipations ne cadrent pas avec l'hypothèse de rationalité, mais sont cependant plus complexes que des attentes purement adaptatives. L'expérience propre à chaque firme, par exemple la dynamique des prix qu'elle prévoit payer (salaires ou intrants), exerce une influence marquée sur les anticipations agrégées. Les auteurs constatent aussi que les anticipations sont fortement et positivement corrélées avec les mouvements des prix du pétrole. Les résultats qui précèdent se confirment en grande partie au niveau de l'entreprise. L'estimation de spécifications tenant compte d'un changement structurel donne à penser que les anticipations d'inflation au Canada ont eu tendance à baisser depuis la Grande Récession. Toutefois, les données n'indiquent pas que les attentes des entreprises canadiennes ne soient plus ancrées.

Classification JEL : C1, C2, C25, D21, D84, E31, E52, E58

Classification de la Banque : Crédibilité; Recherches menées par les banques centrales; Méthodes économétriques et statistiques; Dynamique des entreprises; Cibles d'inflation; Inflation et prix; Cadre de la politique monétaire 


\section{Non-Technical Summary}

It is now widely accepted that inflation expectations influence current inflation and that they matter for the conduct of monetary policy (Coibion and Gorodnichenko 2015b; Clarida et al. 1999). However, relatively little is known about how expectations are formed, particularly those of business leaders.

In this paper, we study how Canadian firms form their inflation expectations, using a unique proprietary dataset of the Bank of Canada, the Business Outlook Survey (BOS). Each quarter, economists from the Bank's five regional offices conduct face-to-face interviews with a representative sample of business leaders throughout Canada to assess their business sentiment. While each interview is akin to a conversation, it follows a structured questionnaire that touches upon several key dimensions of the firm's business (e.g., sales, investments, prices). Most questions asked are qualitative in nature (e.g., are expectations "higher," "lower," "the same"). One question pertains to the firm's expectations regarding the annual rate of inflation over the next two years, based on the Canadian consumer price index.

We use firms' answers to this question to build an aggregate measure of inflation expectations for each quarter (the inflation expectations index - IEI) and study its behavioural properties with reference to the rationality hypothesis. While we find that the IEI is not consistent with the rationality assumption, this is also the case for other measures of inflation expectations, namely, those of the Survey of Professional Forecasters (SPF) and of the Business Confidence Survey (BCS). Nonetheless, given the breadth of BOS data, we present robust stylized facts pertaining to the formation of Canadian firms' expectations. It appears that, even though the expectations of Canadian firms have an adaptive component, they systematically refer to their own personal experience (e.g., wages and input prices) in forming their expectations. Firms' inflation expectations also appear to be significantly and positively influenced by movements in oil prices.

The stylized facts found at the aggregate level also hold at the firm level. Moreover, the important number of observations available at the firm level enables us to shed additional light on the formation of firms' inflation expectations. For example, we find that firms experiencing significant pressures on their production capacity and/or facing labour shortages expect higher inflation.

Finally, we uncover robust evidence, both at the aggregate and firm levels, that the inflation expectations of Canadian businesses have drifted downward since the 2008-09 recession. However, the BOS data do not suggest that expectations have become unanchored since a majority of firms expect inflation to remain within the Bank of Canada's 1 to 3 per cent inflation-control range. 


\section{Introduction}

Canada's recent monetary and inflation history shares many similarities with the U.S. experience. Inflation was well into the double digits at the beginning of the 1980 s and remained quite elevated and variable throughout that decade. However, a major institutional difference between Canada and the United States is that, in 1991, the Bank of Canada (henceforth called the Bank) and the Government of Canada agreed to explicit inflation targets, thus providing what Clarida et al. (1999) refer to as a "clear nominal anchor for [monetary] policy". ${ }^{1}$ Since 1995, the explicit inflation target has been set at 2 per cent, within a control range of 1 to 3 per cent, as measured by the 12-month rate of change in the total consumer price index (CPI) (Murray 2013). Since then, inflation in Canada has averaged 2 per cent and its variability has fallen dramatically. ${ }^{2}$ Canada's inflation history over the past 20 years suggests that the Bank not only fulfilled its mandate but, relative to the period before the introduction of the inflationcontrol agreement, also seems to have significantly influenced the public's inflation expectations (Yetman 2015).

Inflation expectations are a key determinant of actual and future inflation. They play a crucial role in the conduct of monetary policy and its effectiveness (Clarida et al. 1999; Woodford 2005; Kryvtsov and Petersen 2015; Leduc et al. 2007; Boivin 2011; Diron and Mojon 2008). However, relatively little is known about how individual consumers (Armantier et al. 2015) and entrepreneurs form their inflation expectations (Coibion et al. 2015; Blanchflower and MacCoille 2009). ${ }^{3}$ The issue of how firms form their inflation expectations is especially relevant for monetary policy since firms set prices and wages in the economy. Moreover, it is also of interest for the Bank to understand the behavioural properties of the inflation expectations derived from one of its publications, the Business Outlook Survey (BOS). For instance, are these expectations adaptive or rational?

In this paper, using data from the Bank's quarterly BOS from 2001Q2 to 2015Q2, we study how firms form their inflation expectations. First, we aggregate the firm-level data to construct a median measure of expectations, the inflation expectations index (IEI), and study its behavioural properties. The correlation between the IEI and different measures of inflation suggests that the IEI's predictive power

\footnotetext{
${ }^{1}$ Since 25 January 2012, and under the stewardship of Chairman Bernanke, the U.S. Federal Reserve has set itself an explicit inflation target of 2 per cent.

${ }^{2}$ Côté (2015) comes to the same conclusions when starting the analysis in 1991 . The variance of average yearly inflation during 1991-2014 is only a tenth of what it was compared with the 1956-1990 period.

${ }^{3}$ We will use the terms entrepreneurs or firms interchangeably throughout the rest of the paper.
} 
peaks for contemporaneous or one-quarter-ahead inflation. Following the framework of Mankiw et al. (2003), we find that the IEI does not satisfy the rationality assumption along a number of dimensions. However, it is found to incorporate a broader set of information than would be expected on the basis of purely adaptive expectations. Firms' own unique experiences significantly influence their aggregate expectations. For example, the IEI significantly increases with the percentage of firms anticipating an acceleration in the prices they pay (i.e., hourly wages and input prices), even after controlling for typical macroeconomic variables such as the unemployment rate. Inflation expectations are also found to be significantly and positively correlated with movements in oil prices (Coibion and Gorodnichenko 2015a).

We also apply the Mankiw et al. (2003) framework to other measures of inflation expectations, namely those of the Survey of Professional Forecasters (SPF) and of the Business Confidence Survey (BCS). ${ }^{4}$ These provide benchmarks for the IEI. In a similar fashion to the IEI, the analysis suggests that the mean inflation forecasts of both the SPF and the BCS fail to meet the requirements implied by the rationality assumption. A model of enriched adaptive expectations appears compatible with the expectations of the SPF, as in the case of the BOS, but not with those of the BCS.

Using a different methodology (non-linear) and the original micro-data, results obtained at the firm level are consistent with those obtained at the aggregate level. For example, firms' inflation expectations increase with an anticipated acceleration in the prices they pay (i.e., hourly wages and input prices), and exhibit significant positive covariation with movements in oil prices. The extra degrees of freedom available at the micro level enable us to shed additional light on the formation of firms' expectations. Specifically, we find that firms experiencing significant pressures on their production capacity, facing labour shortages, and/or anticipating an increase in the growth rate of the prices they charge (i.e., output prices), expect higher inflation.

Finally, the estimation of specifications with a structural shift, both at the aggregate and at the firm level, suggests that inflation expectations in Canada have drifted downwards since the Great Recession (henceforth the GR) (Ehrmann 2015). However, the BOS data do not suggest that these have become unanchored since a majority of firms expect inflation to remain within the Bank's 1 to 3 per cent inflation-control range.

\footnotetext{
${ }^{4}$ These data are described in Section 2.3.
} 
The rest of the paper is structured as follows. Section 2 presents the data, and Section 3 reports some descriptive analysis of the median measure of the inflation expectations reported in the BOS. Section 4 presents the aggregate-level results, while Section 5 presents the firm-level results. The last section concludes with a brief summary of the main findings.

\section{Data}

In this section, we provide a brief overview of the Bank's quarterly BOS data. We also provide some descriptive analyses of firms' inflation expectations, both at the firm and at the aggregate levels. ${ }^{5}$

\subsection{Data collection process}

Using the BOS data, which started in 199703, we study how entrepreneurs form their inflation expectations. Each quarter, economists from the Bank's five regional offices meet face-to-face with about 100 company representatives who are at the most senior levels of their organizations. ${ }^{6}$ These firm representatives are knowledgeable about the firm's overall past performance and about its prospects. Participation is voluntary.

The survey uses a quota-sampling framework. BOS firms are selected such that the overall sample by quarter matches industry sector weights for business GDP (at basic prices) in Canada (see Table 1). ${ }^{7}$ Hence, the selection of firms in the sample is not random. Nevertheless, using simulations, and under certain assumptions, de Munnik et al. (2013) find that there is "no evidence that the Bank of Canada's firm selection process results in a wider dispersion in the sampling distribution than the stratified random sample." Thus, despite being a non-probabilistic sample, the BOS seems relatively free of bias and broadly representative of the Canadian economy. While industrial composition is one of the primary selection criteria for the BOS sample, each of the five regional offices at the Bank is assigned a fixed number of firms to visit in each survey round, corresponding roughly to the percentages shown in Table 1, to reflect some of the regional diversity of the Canadian economy. Finally, efforts are made to

\footnotetext{
${ }^{5}$ For a detailed overview of the BOS, see Martin and Papile (2004).

${ }^{6}$ The Bank's regional offices are located in: Halifax (representing Atlantic Canada), Montréal (Quebec), Toronto (Ontario), Calgary (the Prairies, Northwest Territories, and Nunavut), and Vancouver (British Columbia and the Yukon). Survey respondents are typically the chief executive officer, president, chief financial officer, chief operating officer or treasurer.

${ }^{7}$ Business sector GDP excludes the public sector. These weights are re-evaluated every two years and are adjusted modestly if and when the industry composition of Canadian business sector GDP has changed materially.
} 
have a diverse sample of firms based on their size, with the aim of having a third of firms of each size (small, medium and large) in the sample. ${ }^{8}$

This quota-sampling framework implies that medium- (large-)sized firms are over- (under-)sampled relative to their share of business sector GDP, as are manufacturers and firms in the Prairies, Atlantic, and British Columbia, while firms in Ontario are undersampled. ${ }^{9}$ One should also keep in mind that, since participants are generally not re-interviewed before two years have elapsed, changes in the survey results over time may in part reflect sample rotation (Martin and Papile, 2004).

\subsection{Questionnaire and the variable analyzed}

The BOS questionnaire can be divided into three categories of questions: (i) questions about business activity; (ii) questions concerning pressures on a firm's production capacity; and (iii) questions on the prices a firm pays and charges, and on its inflation expectations. ${ }^{10}$ All the information contained in the questionnaire is qualitative. ${ }^{11}$ The variables retained for the analysis are the ones available throughout the sample and for which the definition did not change over time.

The analyses presented in this paper are based on firms' inflation expectations over the next two years. Specifically, the analyses rely on the responses to the following question:

"Over the next two years, what do you expect the annual rate of inflation to be, based on the Canadian consumer price index?

$\circ$ below $1 \%$

$\circ$ between $1-2 \%$

○ between $2-3 \%$

○ above 3\%."

\footnotetext{
${ }^{8}$ Firm size is defined by the number of employees: small (fewer than 100), medium (100 to 499) and large (500 or more). In practice, the "firm size" criterion is of tertiary importance relative to industrial and regional composition. ${ }^{9}$ See Table 1 in de Munnik et al. (2013). The manufacturing sector is oversampled relative to its share of business sector GDP in recognition of its extensive linkages to other sectors of the economy.

${ }^{10}$ The BOS questionnaire also includes questions on credit conditions, but there are roughly 20 per cent of missing responses at the firm level. In our analysis, we control for credit conditions by using the prime business loan rate.

${ }^{11}$ The BOS variables used in the analyses (e.g., business activity measures) other than the dependent variable are described in Appendix A.
} 
In practice, interviewers ask firms about the average rate of inflation they expect over the next two years. As a number of researchers have emphasized (Bryan et al. 2015; Bruine de Bruin et al. 2010), the specific framing of a question on inflation can lead to more precise answers. That is the case with the BOS inflation question with its specific reference to headline CPI. The two-year horizon of the question closely coincides with the Bank's policy horizon of 18 to 24 months. The analysis covers the $2001 Q 2$ to $2015 Q 2$ period. $^{12}$

Chart 1 shows that the distribution of inflation expectations (i.e., the percentage of firms that select each option every quarter) broadly follows the business cycle. ${ }^{13}$ Even though the percentage of firms selecting the "below 1 per cent" option spiked during the GR to an all-time high of 42 per cent (2009Q1), it quickly fell back afterwards. Since the end of the GR, and after several years of slow growth during the recovery, the percentage of firms selecting the "above 3 per cent" and the "between 2 and 3 per cent" options have decreased over time. However, Chart 1 does not suggest a potential unanchoring of Canadian business expectations since the GR (i.e., the percentage of firms choosing "below 1 per cent" has remained marginal with a vast majority of firms continuing to expect inflation to be within the Bank's inflation-control range). Moreover, and as of the summer 2014 BOS, a supplemental question was added to identify the probability that each firm assigns to various ranges for future inflation (with the same time horizon as the question above). ${ }^{14}$ As Chart 5 reveals, the average probability assigned by firms to each range of future inflation is consistent with the distribution of beliefs shown in Chart 1 since 2014Q2. Hence, these two pieces of evidence suggest that firms' inflation expectations remain anchored in Canada, at least in the medium term, as is also outlined in the Bank's Monetary Policy Report. ${ }^{15}$

\subsection{Introducing the BOS inflation expectations index (IEI)}

For each quarter, we use the BOS data to compute a summary measure of the central tendency of firms' inflation expectations. This measure, which we refer to as the BOS inflation expectations index (hereafter the IEI), is derived from the median of grouped responses according to the following formula:

\footnotetext{
${ }^{12}$ Before 2001Q2, the inflation expectations question was not as precise, allowing only three response options: $<1$ per cent, 1 to 3 per cent, $>3$ per cent.

${ }^{13}$ Note that only 2.6 per cent of the sample has missing values for inflation expectations.

${ }^{14}$ This was first mentioned in the Bank's Monetary Policy Report of October 2014. As of 2015Q2, the responses to this question are not part of the BOS publication.

${ }^{15}$ See, for example, the October 2014 and July 2015 publications.
} 


$$
I E I=L_{m d}+\left[\frac{\frac{n}{2}-F}{f_{m d}}\right](c),
$$

where $L_{m d}$ refers to the lower bound of the median response option, $F$ represents the cumulative frequency of all response options below the median range, $c$ denotes the width of the median option, $f_{m d}$ denotes the frequency with which respondents selected the median option, and $n$ denotes the total number of respondents. ${ }^{16}$

Chart 2 plots the IEI and inflation. In the years preceding the GR, the IEI rose gradually, coinciding with increases in observed inflation that were largely driven by commodity prices.

Chart 3 shows how the IEI compares with other survey measures of inflation expectations, such as those of the SPF and of the BCS. In its quarterly BCS, the Conference Board of Canada asks 500 CEOs of Canadian businesses about their expectations for price increases over the next six months. ${ }^{17}$ The SPF is a well-known cross-sectional survey of professional forecasters conducted by Consensus Economics on a monthly basis, asking their prediction of inflation for the current year, and for the next year, among other things. ${ }^{18}$ The similarities between the three measures of aggregate expectations are striking, considering that they have different outlook horizons (2-years ahead, 1-year ahead, and 6-months ahead, respectively), different forecast variables (headline CPI inflation for the BOS and the SPF and "prices in general" for the BCS), are forecasted by different groups of agents (professional forecasters for the SPF and firms in the other two), and are computed using different methodologies. ${ }^{19}$

\footnotetext{
${ }^{16}$ Because the median response option has never been either one of the two open-ended intervals, the median-IEI is probably a more suitable measure of expectations than the mean measure proposed by Martin and Papile (2004), since it obviates the need to make assumptions about the end points of the open-ended intervals. In practice, the two measures (i.e., median and mean) are very highly correlated (0.99).

17 Possible responses are "less than 1 per cent," “1, 2, 3, 4, 5, 6, 7, 8 per cent," or "more than 8 per cent." For each quarter, the average expected inflation rate is a weighted average (by percentage of respondents) of answers with the value of the "less than 1 per cent" choice equal to zero, and that of "more than 8 per cent" fixed at 9.

${ }^{18}$ Because SPF forecasts are made for calendar-year values, forecasts from the January and June surveys do not have identical time horizons. For the January surveys, we use the forecast of the current-year values, and for the June surveys, we use a weighted average of current- and next-year values (weights of 7/12 and 5/12 on current and subsequent years, respectively). Finally, each quarterly forecast is simply the average value of the corresponding monthly forecasts.

${ }^{19}$ Despite the similarities discussed here, the mean of the IEI is actually higher than the average of expectations for the SPF as well as for the BCS prior to 2008Q4 (both differences are statistically significant at the 1 per cent level results not shown). This could possibly be explained by the different nature of the respondents (Coibion and Gorodnichenko 2015a; Bryan et al. 2015), and by differences in the outlook horizon (Bryan et al. 2015).
} 


\section{Descriptive Analysis with the BOS IEI}

\subsection{Correlation analysis}

To understand how the IEI evolves with future and past inflation, we take a geometric average of CPI inflation over a two-year period and use $\pi_{t}^{t+8}$ to denote the average rate of inflation over the two years between quarter $t$ and quarter $t+8$, a time horizon that matches the outlook of the question asked in survey quarter $t$. It follows that $\pi_{t-8}^{t}$ denotes the average annual rate of inflation over the two years prior to the survey. Results from correlations using different price indices are reported in Table 2 . The correlation between the IEI and contemporaneous headline CPI is moderately strong $\left(\pi_{t-8}^{t}: 0.63\right.$; see also Chart 2). ${ }^{20}$ However, the correlation between the IEI and the rate of inflation that actually prevails over the forecast horizon is negative $\left(\pi_{t}^{t+8}:-0.30\right)$, suggesting that the IEI does not predict two-yearahead movements in headline inflation very well. ${ }^{21}$

The correlation with core inflation reveals that the low correlation of the IEI with future CPI inflation is not the result of noise introduced by movements in the prices of the most volatile components of the $\mathrm{CPI}$. The contemporaneous correlation with core inflation is weak $\left(\pi_{t-8}^{t}: 0.28\right.$; Table 2$)$, and it becomes negative when core inflation is brought forward to align with the outlook horizon $\left(\pi_{t}^{t+8}:-0.45\right)$.

Results are qualitatively similar when using gasoline price inflation instead of headline CPI inflation (Table 2). About two-thirds of firms interviewed during BOS visits are small- and medium-sized and, as Coibion and Gorodnichenko (2015a) underscore, most of these firms do not have a professional forecaster on staff. Hence, one possible interpretation of these results is that a non-trivial fraction of BOS respondents answer the inflation question with the mindset of consumers/households and are implicitly referring mostly to the prices of goods that they, as consumers, purchase on a regular basis. ${ }^{22}$

The correlation of the IEI with the Canadian GDP deflator (a proxy for production prices) is moderately

\footnotetext{
${ }^{20}$ As in Martin and Papile (2004), the following scale is used to evaluate the correlation: strong: > 0.80, moderately strong: 0.80 to 0.60 , moderate: 0.60 to 0.40 , weak: 0.40 to 0.20 .

${ }^{21}$ We recalculated the correlations shown in Table 2 using annual inflation rates (i.e., y/y). The results (Table B1 Appendix B) show that, in general, the IEI is a better predictor of two-year average rates of inflation than of the annual rates of inflation (i.e., y/y).

${ }^{22}$ Since 2009, Bank economists have been recording the details firms provide on what is driving their expectations when answering the inflation question. A rough classification of responses (by keywords) suggests that the prices of commodities and commodities-related products (e.g., food, gasoline, etc.) are the most frequently cited drivers of firms' inflation expectations.
} 
strong $\left(\pi_{t-8}^{t}: 0.71 ;\right.$ Table 2$)$. This suggests that respondents might (also) be answering in reference to industry-specific price indices (Bryan and Venkatu 2001).

There is also a moderately strong correlation between the IEI and contemporaneous U.S. CPI inflation $\left(\pi_{t-8}^{t}: 0.66\right)$. While part of this result can perhaps be attributed to the fact that firms' perspectives are strongly influenced by economic developments within the United States, it is also the case that the U.S. CPI itself is highly correlated with movements in energy prices.

Finally, we also calculate correlations between the IEI and a one-period lag of our different measures of inflation $\left(\pi_{t-9}^{t-1}\right)$ in order to isolate a measure of past inflation that is likely to have been accessible to survey participants given publication lags. We see that for each of the four measures of inflation, the correlations are positive when using the one-quarter lag, though not as strong as they are found to be when using the contemporaneous inflation measures. It is worth noting that the analysis is performed on quarterly data, whereas actual inflation data are available on a monthly basis. Hence, firms already have one or two months of available information on inflation in the quarter in which they are interviewed.

\subsection{Forecasting performance}

To formally evaluate the forecast accuracy of the IEI, we calculate its root-mean-squared error (RMSE) and its mean absolute error (MAE), where, for any given quarter, the forecast error corresponds to the difference between the IEI at time $t, \mathrm{E}_{\mathrm{t}} \pi_{t}^{t+8}$, and $\pi_{t}^{t+8}$ (Chart 4). We then benchmark the performance of the IEI by comparing it to a naïve forecast equal to a one-quarter lag of CPI inflation over the past two years $\left(\pi_{t-9}^{t-1}\right)$, as well as to a forecast equal to the Bank's inflation target of 2 per cent. Table 3 indicates that, on the basis of the RMSE and the MAE, the IEI might be a slightly better predictor than the naïve forecast, but it underperforms relative to the Bank's inflation target.

Moreover, we also compare the forecasting performance of the IEI with other inflation forecasts, namely those of the SPF and of the BCS. Interestingly, the IEI outperforms both the SPF and BCS mean inflation forecasts, whichever measure of forecast accuracy is considered, and once the inflation rate to be predicted is adjusted to match the time horizon of the survey question being considered. 


\section{Macro-Level Results}

Using quarterly data, we test whether the BOS median inflation expectations (IEI) are rational or adaptive, before developing models of expectations that incorporate firm-level variables from the BOS. ${ }^{23}$ Throughout most of this section, we also compare the behavioural properties of the IEI with those of the SPF and the BCS mean inflation forecasts. ${ }^{24}$

\subsection{Testing the rationality of expectations}

Rational inflation expectations imply that all relevant information is used efficiently when forming expectations of future inflation. Rational inflation forecasts should be free of systematic and predictable errors. Thus, in order to reject the rationality assumption, it is sufficient to show that forecast errors are, in fact, predictable. In testing whether forecast errors are suggestive of a departure from the rationality hypothesis, our analysis closely follows the framework of Mankiw et al. (2003), but many other studies have used or discussed similar tests (Andolfatto et al. 2008; Forsells and Kenny 2002; Mehra 2002; Thomas 1999; Roberts 1997; Ball and Croushore 2003; and Croushore 1997). We perform the analysis using the median measure of inflation expectations presented in the previous section (IEI). ${ }^{25}$

Table 4 shows that, over the sample period, BOS firms had a tendency to overestimate inflation, contrary to professional forecasters (SPF) or firms surveyed in the BCS. However, this piece of evidence against the rationality hypothesis can be viewed as rather weak in the case of the BOS. Since the forecast horizon of two years is long relative to the frequency at which forecasts are generated (quarterly), the horizons of successive forecasts overlap. Thus, an unanticipated shock to the economy can cause several successive forecast errors to have the same sign. Such a situation occurred when

\footnotetext{
${ }^{23}$ All the estimations in Sections 4 and 5 are unweighted since the BOS data are based on quota sampling (Section 2.1).

${ }^{24}$ We also repeated the analyses of Sections 4 and 5 for the subsample of BOS manufacturing firms to examine the extent to which firms' inflation expectations might be in reference to industry-specific prices (Bryan and Venkatu 2001) rather than consumer prices (the subject of the BOS question). The results (not shown but available upon request) were essentially the same as those presented in the paper, suggesting that BOS firms' expectations are influenced both by industry-specific price indices and by the CPI inflation rate.

${ }^{25}$ Ideally, however, this type of analysis would be performed using individual responses at the firm level. Since most firms in our sample answer the inflation expectations question by selecting an interval without giving a point estimate (almost 75 per cent), it is not possible to precisely quantify forecast errors. For this reason, we perform the econometric tests of rationality using aggregated data, as given by the IEI.
} 
inflation dropped precipitously during the GR. As a result of this drop, successive forecasts made prior to $2008 \mathrm{Q} 4$ overestimated realized inflation (Chart 4). ${ }^{26}$

As implied above, rational forecasts should be devoid of any informative content as far as predicting the corresponding forecast errors is concerned. Table 5 illustrates that this is not the case with the IEl. The coefficient on the IEI is highly significant, indicating that the BOS median inflation forecasts are predictive of subsequent forecast errors. This conclusion also applies to the SPF and to the BCS mean inflation forecasts.

Another corollary of the rationality assumption is that all relevant macro information available at the time the forecasts are made should not help predict subsequent forecast errors. Table 6 suggests that such a condition is not met with the IEI since the coefficients corresponding to past inflation, interest rates, and the unemployment rate are jointly significant. Results are similar for the forecasts of both the SPF and the BCS.

Finally, rational forecasts also imply an absence of persistence in forecast errors. Table 7 provides further evidence that the rationality assumption is not met by the forecasts of the BOS, the SPF and the BCS.

Overall, the evidence presented thus far suggests that the BOS median inflation forecasts are not consistent with the rationality assumption. We reach similar conclusions for the mean inflation forecasts of both the SPF and the BCS. ${ }^{27}$

\footnotetext{
${ }^{26}$ We are testing for a strong form of rationality. Hence, our results offer no insights on a less-stringent form of rationality such as, for example, bounded rationality, in which agents are assumed to have a limited ability to gather and process information, or face uncertainty about the true economic model while retaining some elements of rationality in their decision-making process.

${ }^{27}$ Coibion and Gorodnichenko (2012) provide a complementary explanation for these results: "[...] information rigidities are likely to be an important component of the expectations formation process for consumers, firms, and central bankers as well as professional forecasters." See also Coibion and Gorodnichenko (2015b). Overall, the results presented in this subsection and the next are qualitatively similar to those of Mankiw et al. (2003).
} 


\subsection{Testing models of adaptive expectations}

Having uncovered similar evidence against the rationality assumption for the BOS, as well as for the SPF and $\mathrm{BCS}$, we now explore the possibility that the expectations reported in these surveys are compatible with a framework of adaptive expectations.

The three columns of Table 8 report results of regressions of the IEI on different lagged measures of CPI inflation (i.e., 2-year average, y/y, and q/q). These results suggest that the IEI is somewhat backwardlooking.

We then enrich these regressions by adding the current and lagged values of interest rates and the unemployment rate (cf. Mankiw et al. 2003), and apply this to the three surveys considered. Results for the BOS and SPF are broadly similar (Table 9), and suggest that expectations are not purely adaptive and account for more information than just the lagged inflation. The coefficients on the interest rate and the unemployment rate are found to be highly significant.

Interestingly, in the context of an enriched adaptive expectations framework, the estimates reported in the third column of Table 9 suggest that the BCS expectations cannot be explained by past observations of inflation, the coefficients on lagged inflation being non-significantly different from zero. This is quite surprising given the short forecasting horizon of this survey (6 months; Ehrmann 2015). However, and as in the cases of the BOS and SPF, the unemployment rate and the short-term interest rates are found to help predict inflation expectations.

\subsection{Using BOS data to build a model of inflation expectations formation}

We now broaden the information set that firms may be drawing upon when forming their expectations. Specifically, we incorporate and test the explanatory power of firm-level variables from the BOS, expressed as a balance of opinion, that is, the percentage of positive responses minus the percentage of negative responses. For example, firms expecting increased (decreased) input price pressures might systematically forecast higher (lower) levels of future inflation. It is thus possible that respondents draw

upon their firm-specific experience to make generalizations about aggregate activity. If such a systematic generalization of individual experience is indeed taking place, then it should be reflected at the aggregate level (i.e., in the IEI). Aggregate expectations should thus be partly explained by balances of opinion, even after controlling for typical macroeconomic variables (e.g., unemployment). 
As our starting point, we use a more parsimonious version of the regression model examined in Table 9 since we have a small sample period $(T=57)$. Our baseline model includes past inflation, the lagged unemployment rate and the lagged growth rate in the price of WTI crude oil. ${ }^{28}$ We also control for the latter, given its importance in the formation of expectations (Coibion and Gorodnichenko, 2015a).

We proceed by using a stepwise regression procedure, where we add/remove new explanatory variables, almost all of which are drawn from the BOS, to/from our baseline model. If a single variable increases the adjusted $R^{2}$, both in absolute terms and relative to the inclusion of all other available variables, we opt to keep it in the model. Repeating this iterative procedure and applying judgment to keep the model parsimonious provides the selected models presented in Table 10.

Past or current inflation, the lagged unemployment rate, and the lagged growth rate in the price of WTI crude oil are all significant determinants of the aggregate level of firms' inflation expectations. Moreover, their effect is as expected. Increases in inflation and crude oil prices tend to increase firms' inflation expectations, while a rise in the unemployment rate lowers their expectations. ${ }^{29}$

The balances of opinion on firms' outlook for wages and input prices are both part of the selected models. Each coefficient is positive and significant, even after controlling for the macroeconomic environment. These results suggest that respondents are systematically referring to their firm-specific experience when making generalizations about aggregate activity.

Another variable included in the selected models is a crisis-period/post-recession indicator. This indicator is equal to one at every quarter from 2008Q4 onwards. ${ }^{30}$ It is thus possible that its significance is attributable exclusively to the recession period (2008Q4 to 2009Q2), in which case the structural shift may have only been temporary. We redefine this variable along the dates proposed by Friedrich and

\footnotetext{
${ }^{28}$ We chose to keep the unemployment rate in the baseline model since it can be seen as an indicator of macroeconomic slack, but keeping the prime rate instead yields similar results. We obtain the same results in terms of variables entering the preferred model when using contemporaneous inflation (Table 10; column 2) rather than past inflation (column 1), albeit with a better fit for the former. Hence, we use current inflation in the rest of the estimations.

${ }^{29}$ The effect of the oil price variable is not materially changed if the price of WTI crude oil is expressed in Canadian dollars.

${ }^{30} 2008 \mathrm{Q} 4$ is the official date of the start of the GR in Canada according to the C.D. Howe Institute's Business Cycle Council.
} 
Gosselin (2015) to test the robustness of the preceding results. ${ }^{31}$ In all cases, the effect is negative and significant, suggesting that expectations in Canada have drifted downwards since the Great Recession/crisis period (Ehrmann 2015).

\section{Micro-Level Results}

In this section, we model inflation expectations using the BOS data at the firm level. Given the ordinal nature of the dependent variable, with response ordering going from "below $1 \%$ " to "above $3 \%$," such that larger values are assumed to correspond to "higher" outcomes, we model inflation expectations by estimating ordinal logistic regressions. ${ }^{32}$ Finally, we estimate a model with a structural shift to test whether findings from the macroeconomic analysis are supported by the micro-level data. ${ }^{33}$

\subsection{Ordinal logistic regression results}

To better understand how expectations are formed at the firm level, we start with the following form, which is estimated by ordinal logistic regression:

$$
\begin{gathered}
I E_{i t}=\alpha^{*} \text { PastSales_Negative } i t+6{ }^{*} \text { PastSales_Positive } i t \\
+\mu^{*} \text { PastSales_Decline }_{i t} \\
+v^{*} X_{i t}+\varphi^{*} \text { macro }_{t-1}
\end{gathered}
$$

where $I E_{i t}$ corresponds to firm i's inflation expectations at date $t$, PastSales_Negative ${ }_{i t}$ takes the value of 1 if the firm reports a slower growth rate in its sales volumes over the past 12 months, and PastSales_Decline $_{i t}$ is equal to 1 if the firm registered a decline in the level of its sales volumes during the past year. ${ }^{34} X_{i t}$ is a vector containing the rest of the BOS qualitative firm-level variables (specified in a similar way as for past sales) measured at date $t$, and $\gamma^{\prime}$ is a vector of parameters. macro $_{t-1}$ is a vector of

\footnotetext{
${ }^{31}$ Friedrich and Gosselin (2015) define the following periods: (i) crisis period (2007Q4 to 2009Q3); (ii) early postcrisis period (2009Q4 to 2011Q4); and (iii) late post-crisis period (2012Q1 to 2014Q2). Appendix C reports the estimation results.

${ }^{32}$ Given that the dependent variable contains open-ended intervals, another option would have been to estimate an interval regression. The results of this estimation strategy are presented in Table D1 (Appendix D), along with those of ordinal probit and logit regressions. The results are qualitatively similar across estimation strategies.

${ }^{33}$ Those results can also be found in Appendix D (Table D3).

${ }^{34}$ Obviously, if a firm reports PastSales_Positive ${ }_{i t}$ then, necessarily, PSales_Negative ${ }_{i t}$ is equal to 0 for that firm. The reference category is PastSales_Same it.
} 
macroeconomic variables (Table 11) and $\varphi^{\prime}$ is a vector of parameters. We use 5,376 observations spanning from 2001Q2 to 2015Q2 for which we have no missing values on any of the variables used. ${ }^{35}$

Table 11 shows the results when all the BOS firm-level indicators and macroeconomic variables are included in the model. ${ }^{36}$ The goodness of fit, as measured by the McFadden pseudo- $R^{2}$, is relatively low (8.9 per cent). However, the Wald $\mathrm{Chi}^{2}$ test for overall model fit is significant at the 1 per cent level. Given the number of explanatory variables included in the model, we present only the coefficients of variables that belong to the same BOS question and that are jointly significant determinants of firms' expectations. For example, in equation (1), it is evident that the Past Sales variables belong to the same BOS question. Hence, the individual coefficients of these variables are presented in Table 11 only if the coefficients $\alpha, 6$, and $\mu$ are jointly significant. ${ }^{37}$

The coefficients presented in Table 11 are expressed in terms of odds ratios, meaning that if a coefficient is significantly larger (smaller) than one, the likelihood that the respondent will select a higher category of expected inflation increases (decreases). Since all the BOS variables used are qualitative, they have been dichotomized, and the coefficients/odds ratios are expressed relative to a reference category. For example, a firm that reports a slower growth rate in its sales volumes over the past 12 months compared with the previous 12 months (past sales conditions are negative) typically thinks that the odds of inflation being higher than 3 per cent are roughly 0.84 times lower than the odds of it being less than or equal to 3 per cent, and that is relative to a firm that reports a stable growth rate of its past sales volumes (past sales conditions are the same) ${ }^{38}$ Interestingly, reporting significant difficulties, but not some difficulties, in meeting an unexpected increase in demand, significantly increases the odds (by roughly 1.3) of expecting higher inflation. This result is relative to firms that

\footnotetext{
${ }^{35}$ The results of Brant tests (1990) reject the proportional odds assumption. However, the results of the more complex generalized ordered logit regression were very similar to those presented here (Appendix E). We are grateful to Richard Williams (University of Notre Dame) for making his Stata routine (Gologit2) available for the generalized ordered logistic estimation.

${ }^{36} \mathrm{~A}$ model excluding the macro variables but including year effects was estimated, and the results remain essentially unchanged (Table D1 - column (4) - Appendix D). The corresponding Wald $\mathrm{Chi}^{2}$ test strongly rejected the null hypothesis of jointly zero coefficients on the year dummies. However, since we already control for the general macroeconomic environment, including these year effects in the model appears redundant, which is confirmed when performing collinearity diagnostics on the variables present in the model when the year dummies are included. Hence, year dummies are not included in the micro-level analysis.

${ }^{37}$ See Table 11, BOS Explanatory Variables Globally Significant: YES/NO - joint Wald Chi ${ }^{2}$ tests. The complete list of results corresponding to Table 11 is available in Table D2 (column (1) - Appendix D).

${ }^{38}$ Because of the proportional odds assumption underlying the ordinal logistic model, a variable (e.g., past sales conditions are negative) will have the same effect across expected inflation categories.
} 
would have no difficulty in meeting an unexpected increase in demand. Experiencing labour shortages also increases the odds of expecting higher inflation. Note also that large firms tend to forecast lower inflation relative to medium-sized firms. ${ }^{39}$

Turning to BOS price variables, if a firm anticipates an acceleration in the growth rate of the wages it pays (wage outlook is positive), then it is significantly more likely to expect higher inflation. Results suggest that the outlook for input and output price growth exert the same influence as wages on firms' inflation expectations. Moreover, BOS respondents are also asked whether they expect those prices to decline (in levels) over the next 12 months. The estimation results show that a firm anticipating a decline in its input prices will tend to expect lower inflation relative to a firm that does not anticipate such a decline. Similarly, a firm expecting its selling prices to decline will opt for a lower inflation expectations range than a firm not expecting a reduction in its prices. ${ }^{40}$

Regarding the general business environment variables included in the firm-level analysis, overall, the results are consistent with economic intuition and recent research (e.g., Coibion and Gorodnichenko 2015a). For example, if the price of WTI crude oil increased last quarter, it significantly increases the odds that a firm will anticipate higher inflation in the current quarter. That is also the case for real GDP growth in Canada and inflation. Finally, an increase in borrowing costs (i.e., the prime short-term business interest rate) appears to be significantly associated with higher expected inflation.

Overall, the firm-level results are in line with the results found at the aggregate level. For example, the outlook for wages and input prices appears to be an important determinant of firms' expectations, both at the aggregate and the firm level. Hence, the firm-level results seem to reinforce the notion that entrepreneurs draw on their firm-specific experience to make generalizations about aggregate activity. Oil prices also appear to play an important role in the formation of firms' expectations, and results at

\footnotetext{
${ }^{39}$ To assess the extent to which this result might find some support at the aggregate level, we compute the IEI for the subsample of BOS large firms and find that its bias is closer to zero than for the whole sample (Table 4 column (1)) and non-significantly different from zero (results available upon request).

${ }^{40}$ Because there is a certain degree of collinearity between a variable expressing a negative outlook or conditions and the corresponding variable reporting a decline in the level (e.g., past sales conditions are negative and past sales decline), we checked the robustness of the results by dropping the decline variables (i.e., "declines") from the model. The results remain virtually unchanged (see Table D2 - column (2), Appendix D). Note that the highest correlation between two such variables is roughly 0.6 (i.e., between past sales conditions are negative and past sales decline), while other such correlations (i.e., between a negative outlook variable and the corresponding decline variable) range between 0.3 and 0.4 .
} 
the firm level suggest that their effect is, overall, statistically stronger than what was found at the aggregate level.

\subsection{Structural shift specification}

We now explore, at the firm level, whether there has been a structural shift in firms' inflation expectations since the GR, and if it has led BOS variables to have a different effect on expectations since then. Hence, we build on (1) and start with the following form:

$$
\begin{aligned}
& I E_{i t}=\omega^{*} G R \_ \text {indicator }{ }_{t}
\end{aligned}
$$

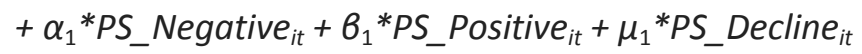

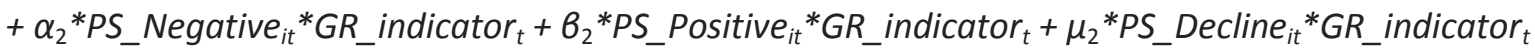

$$
\begin{aligned}
& +\gamma^{*} Z_{i t}+\varphi^{*} \text { macro }_{t-1}
\end{aligned}
$$

where GR_indicator ${ }_{t}$ takes the value of 1 if the period of observation corresponds to the start of the GR in Canada, or after, as in the aggregate estimations. In addition to variables defined in (1), we include terms that aim to capture the potentially different effects of the BOS variables on expectations since the GR: the BOS variables in (1) are interacted with the GR_indicator ${ }_{t}$. Conceptually, the coefficients of interacted variables such as PS_Negative ${ }_{i t}{ }^{*} G R \_$indicator can be interpreted as Difference-in-Differences (DD) (e.g., Angrist and Krueger 1999) estimators.

Table 12 presents the results of the base model in column 1 (same coefficients as in Table 11 for the variables shown) and those obtained with a structural shift in column 2 . A global Wald $\mathrm{Chi}^{2}$ test performed on the interacted BOS variables after estimating the latter (column 2) strongly rejects the null of jointly zero coefficients. ${ }^{41}$ However, the inclusion of all the interacted BOS variables results in higher standard errors of the estimates, potentially suggesting the presence of irrelevant variables in the

\footnotetext{
${ }^{41}$ See Table 12 - Overall Wald Chi $^{2}$ significance test of interacted BOS variables.
} 
model. As before, we only present the coefficients of the interacted variables that belong to the same BOS question and that are jointly significant determinants of firms' expectations. ${ }^{42}$

The value of the coefficient $\omega$ associated with the GR variable, at roughly 0.5 , suggests that the odds of anticipating higher inflation have fallen since the Great Recession relative to before. ${ }^{43}$

As we rely conceptually on the DD methodology for the interacted BOS variables, the interpretation of their coefficients is relatively straightforward: they are ratios of odds ratios. For example, before the GR, a firm anticipating an increase in the growth rate of its input prices (input price outlook is positive) was significantly more likely to expect higher inflation (columns 1 and 2). The coefficient of that variable interacted with the GR indicator (since the GR: input price outlook is positive) is less than one (approximately 0.8). Since the GR, it is still the case that a firm anticipating an increase in the growth rate of its input prices is more likely to expect higher inflation. However, the associated upward pressure on the odds of expecting higher inflation is less important than before the GR since the coefficient of the interacted variable is less than unity. ${ }^{44}$

We test the robustness of the preceding results by, first, building on the fact that a number of the interacted BOS variables are not jointly significant and, second, choosing start dates for the GR/postrecession indicator using the dates proposed by Friedrich and Gosselin (2015). ${ }^{45}$ As we noted earlier, the inclusion of all the interacted BOS variables results in higher standard errors of the estimates, potentially suggesting the presence of irrelevant variables in (2). Hence, the first step of the robustness checks consists of removing all the non-jointly significant interacted BOS variables from (2). The second step consisted of redefining the GR/post-recession indicator using the dates proposed by Friedrich and Gosselin. The robustness checks allow us to draw two main conclusions. First, the coefficients of the remaining interacted $\mathrm{BOS}$ variables become marginally significant upon changing the starting date of the $\mathrm{GR} /$ post-recession indicator, suggesting that the differentiated effects of the BOS variables are not

\footnotetext{
${ }^{42}$ For example, the individual coefficients of the Past Sales variables are presented in Table 12 only if the coefficients $\alpha_{2}, B_{2}$ and $\mu_{2}$ in (2) are jointly significant (Table 12 - column (2), BOS Explanatory Variables Globally Significant: YES/NO - Past Sales since the GR).

${ }^{43}$ Specifically, the odds of expecting inflation to be higher than 3 per cent are roughly 0.5 times lower than the odds of it being lower than or equal to 3 per cent since the GR.

${ }^{44}$ By disaggregating this ratio of odds ratios, it can be verified that it is indeed the case that the odds ratio associated with the positive input price outlook is smaller since the GR.

${ }^{45}$ Results can be found in Appendix D (Table D3).
} 
robust. ${ }^{46}$ Second, the coefficient associated with the GR/post-recession indicator remains highly statistically significant and less than unity in all specifications.

Overall, the estimated effects of the macroeconomic variables do not change materially in the structural shift specification, although the unemployment rate is now significant. However, the robustness checks reveal that the growth rates of Canada's real GDP and of the price of WTI crude are the most robust effects across specifications, with the latter being strongly significant and positive.

Taken together, the evidence does not strongly support the notion that a firm's unique experience (e.g., the dynamic of its input prices) is having a different effect on its inflation expectations since the GR relative to before. However, the structural shift specifications do suggest that there has been an overall downward drift of firms' inflation expectations in Canada since the GR. These firm-level results are similar to those found at the aggregate level.

\footnotetext{
${ }^{46}$ The only exception being the ratio of odds ratios for Output Prices Outlook: Negative, which indicates that, since the GR, the odds of anticipating higher inflation actually increase with an anticipated decrease in the growth rate of output prices, a rather counterintuitive result.
} 


\section{Conclusions}

Inflation expectations matter for the conduct of monetary policy, especially since beliefs can be self-fulfilling, and since they affect the monetary policy transmission mechanism. Firms' inflation expectations are especially relevant for monetary policy as firms contribute to setting prices and wages in the economy. Although new empirical studies are shedding light on the subject, there are still relatively few of these studies, given the dearth of appropriate data, especially at the firm level. To our knowledge, this paper is the only such study for Canada. We contribute to the literature by using data gathered by the Bank of Canada in the context of its quarterly Business Outlook Survey from 2001Q2 to 2015Q2. These data are broadly representative of the Canadian private sector economy.

At the aggregate level, our results show that although firms' inflation expectations are not consistent with the rationality assumption, they are more complex than purely adaptive. For example, we find that inflation forecasts are predictive of future forecast errors, which should not be the case if the information available at the time of the forecast were fully exploited. The fact that BOS firms' expectations are not rational corroborates similar conclusions drawn from a number of other studies. Moreover, we find that firms' expectations are significantly influenced by forward-looking information primarily gathered at the firm level (e.g., input prices and wage expectations), suggesting that firms form their expectations about the evolution of inflation in part by generalizing on the basis of their own experience. As in recent research, we find that firms' expectations are significantly and positively influenced by oil prices, a result reinforced by the firm-level analysis. The estimation of structural shift specifications suggests that inflation expectations have drifted downwards since the Great Recession. However, the BOS data suggest that these expectations are still anchored, since a majority of firms expect inflation to remain within the Bank's 1 to 3 per cent inflation-control range.

Moreover, we use inflation expectations data from both the Survey of Professional Forecasters (SPF) and the Business Confidence Survey (BCS) to compare results obtained with aggregate data from the BOS. As in the case of the BOS, our analysis suggests that both the SPF and the BCS forecasts are not consistent with the rationality hypothesis. Finally, and somewhat similarly to the BOS, a model of enriched adaptive expectations seems compatible with how forecasters from the SPF, but not firms from the BCS, form their inflation expectations. 
The rest of firm-level analyses corroborate most of the aggregate-level results. A number of firm-level variables seem to systematically affect the formation of firms' inflation expectations. Overall, results at the firm level are consistent with economic intuition. For example, a firm that expects increased pressures on the prices it pays (i.e., hourly wages and input prices) or charges (i.e., output prices) tends to expect higher inflation, while a firm that anticipates a decline in these prices tends to expect lower inflation. Furthermore, firms reporting labour shortages or significant pressures on their production capacity generally expect higher inflation. Interestingly, the estimation of structural shift specifications at the firm level yields similar results to those found at the aggregate level: firms' expectations in Canada seem to have drifted downwards since the Great Recession.

In this paper, we use two different methodologies to map aggregate- and firm-level expectations on somewhat similar information sets and find similar results in both cases. Hence, even though we are not testing the implications of a specific theoretical model of firm behaviour, we believe this study uncovers relatively robust empirical evidence shedding light on: (i) how firms form their inflation expectations; (ii) the behavioural properties of these expectations; and (iii) how these expectations might be affected by a significant macroeconomic shock. 


\section{References}

Andolfatto, D., S. Hendry, and K. Moran (2008). "Are Inflation Expectations Rational?" Journal of Monetary Economics, 55 (2): 406-422.

Angrist, J., and A. Krueger (1999). "Empirical strategies in labor economics. " In: Ashenfelter, O., and D. Card, The Handbook of Labor Economics, vol. 3A., North-Holland, Amsterdam, pp. 1277-1366.

Armantier, O., Nelson, S., G. Topa, W. van der Klaauw, and B. Zafar (2015). "The Price is Right: Updating Inflation Expectations in a Randomized Price Information Experiment." Forthcoming, Review of Economics and Statistics.

Ball, L. and D. Croushore (2003). "Expectations and Effects of Monetary Policy." Journal of Money, Credit, and Banking, 35 (4): 473-484.

Bank of Canada (2014). Monetary Policy Report, October.

Bank of Canada (2015). Monetary Policy Report, July.

Bernanke, B. S. (2012). "Transcript of Chairman Bernanke's Press Conference," FOMC press conference, January 25.

Blanchflower, D.G. and C. MacCoille (2009). "The Formation of Inflation Expectations: An Empirical Analysis for the UK." NBER Working Paper 15388.

Boivin, J. (2011). "How people think and how it matters." Speech made before the Canadian Association for Business Economics, Kingston, Ontario, August 23.

Bruine de Bruin, W., S. Potter, R. Rich, G. Topa, and W. van der Klaauw (2010). "Improving Survey Measures of Household Inflation Expectations." Federal Reserve Bank of New York, Current Issues in Economics and Finance, 16 (7): 1-7.

Bryan, M. F., B.H. Meyer, and N. P. Parker (2015). "The Inflation Expectations of Firms: What Do They Look Like, Are They Accurate, and Do They Matter?" Federal Reserve Bank of Atlanta, Working Paper 2014-27a.

Bryan, M. F. and G. Venkatu (2001): "The Demographics of Inflation Opinion Surveys,"

Economic Commentary (October 15).

Clarida, R., J. Gali, and M. Gertler (1999). "The Science of Monetary Policy: A New Keynesian Perspective." Journal of Economic Literature, 37 (4): 1661-1707.

Coibion, O. and Y. Gorodnichenko (2015a). "Is the Phillips Curve Alive and Well after All? Inflation Expectations and the Missing Disinflation." American Economic Journal: Macroeconomics, 7 (1): 197-232.

Coibion, O., and Y. Gorodnichenko (2015b). "Information Rigidity and the Expectations Formation Process: A Simple Framework and New Facts." American Economic Review, 105 (8): 2644-2678. 
Coibion, O., and Y. Gorodnichenko (2012). "What Can Survey Forecasts Tell Us about Information Rigidities?" Journal of Political Economy, 120 (1): 116-159.

Coibion, O., Y. Gorodnichenko, and S. Kumar (2015). "How Do Firms Form their Expectations? New Survey Evidence." NBER Working Paper 21092.

Côté, A. (2015). "L'inflation, les attentes et la politique monétaire." Speech made before the Association québécoises des technologies, Mont-Tremblant, Québec, February 19.

Croushore, D. (1997). "The Livingston Survey: Still Useful After All These Years." Business Review, March/April: 1-12.

de Munnik, D., M. Illing, and D. Dupuis (2013). "Assessing the accuracy of non-random business conditions surveys: a novel approach." Journal of the Royal Statistical Society, 176 (2): 371-388.

Diron, M. and B. Mojon (2008). "Are inflation targets good inflation forecasts?" Federal Reserve Bank of Chicago, Economic Perspectives, 2Q/2008: 33-45.

Ehrmann, M. (2015). “Targeting Inflation from Below - How Do Inflation Expectations Behave?" International Journal of Central Banking, 11 (S1): 213-249.

Forsells, M. and G. Kenny (2002). "The Rationality of Consumers' Inflation Expectations." European Central Bank, Working Paper No. 163.

Friedrich, C. and M.-A. Gosselin (2015). "Inflation Dynamics in the Post-Crisis Period." Bank of Canada Review, Spring: 1-12.

Kryvtsov, O. and L. Petersen (2015). "Expectations and Monetary Policy: Experimental Evidence." Simon Fraser University Working Paper.

Leduc, S., K. Sill, and T. Stark (2007). "Self-fulfilling expectations and the inflation of the 1970s: Evidence from the Livingston Survey?" Journal of Monetary Economics, 54 (2): 433-459.

Mankiw, N. G., R. Reis, and J. Wolfers (2003). "Disagreement About Inflation Expectations." NBER Macroeconomics Annual, 18: 209-248.

Martin, M. and C. Papile (2004). "The Bank of Canada Business Outlook Survey: An Assessment." Bank of Canada, Working Paper 2004-15.

Mehra, Y. P. (2002). "Survey Measures of Expected Inflation: Revisiting the Issues of Predictive Content and Rationality." Federal Reserve Bank of Richmond, Economic Quarterly, 88 (3): 17-36.

Murray, J. (2013). "Monetary Policy Decision Making at the Bank of Canada." Bank of Canada Review, Autumn: 1-9.

Roberts, J. M. (1997). “Is Inflation Sticky?” Journal of Monetary Economics, 39 (2): 173-196. 
Thomas, L. B. (1999). "Survey Measures of Expected U.S. Inflation." The Journal of Economic Perspectives, 12 (4): 125-144.

Woodford, M. (2005). “Central Communication and Policy Effectiveness." NBER Working Paper 11898.

Yetman, J. (2015). "The evolution of inflation expectations in Canada and the US." Bank for International Settlements, Working Paper no. 523. 


\section{Tables and Charts}

Table 1: Summary Statistics on the Firms in the Business Outlook Survey Sample $-2001 Q 2$ to $2015 Q 2$

\begin{tabular}{|c|c|c|c|c|c|}
\hline Sector & $\%^{\mathrm{a}}$ & Region & $\%^{a}$ & Size $^{b}$ & $\%^{a}$ \\
\hline Primary & 8.4 & Atlantic & 14.5 & Small & 29.3 \\
\hline Manufacturing & 26.3 & Quebec & 20.7 & Medium & 33.4 \\
\hline $\begin{array}{l}\text { Construction, information, transportation } \\
\text { services and utilities }\end{array}$ & 19.4 & Ontario & 25.3 & Large & 37.2 \\
\hline Wholesale and retail trade & 14.9 & Prairies & 19.8 & & \\
\hline Finance, insurance and real estate & 13 & $\begin{array}{l}\text { British } \\
\text { Columbia }\end{array}$ & 19.8 & & \\
\hline $\begin{array}{l}\text { Commercial, personal and business } \\
\text { services }\end{array}$ & 18 & Total Obse & & $N=$ & 5,376 \\
\hline
\end{tabular}

Notes:

a. Percentages may not add to 100 because of rounding.

b. Small firms employ 1 to 99 persons; medium-sized firms, 100 to 499; while large firms employ 500 people or more. 
Table 2: Correlation Between BOS IEI and Various Inflation Indicators (per cent, 2-year avg.; 2001Q2 to $2015 Q 2$ - GDP deflator until 2015Q1)

\begin{tabular}{|c|c|c|c|c|c|c|c|c|c|c|}
\hline Measure of Inflation & $\pi_{t-9}^{t-1}$ & $\pi_{t-8}^{t}$ & $\pi_{t-7}^{t+1}$ & $\pi_{t-6}^{t+2}$ & $\pi_{t-5}^{t+3}$ & $\pi_{t-4}^{t+4}$ & $\pi_{t-3}^{t+5}$ & $\pi_{t-2}^{t+6}$ & $\pi_{t-1}^{t+7}$ & $\pi_{t}^{t+8}$ \\
\hline CPI Inflation Rate & 0.39 & 0.63 & 0.62 & 0.54 & 0.48 & 0.37 & 0.33 & 0.29 & 0.04 & -0.30 \\
\hline Core CPI Inflation Rate & 0.25 & 0.28 & 0.22 & 0.12 & 0.03 & -0.10 & -0.20 & -0.23 & -0.31 & -0.45 \\
\hline GDP Deflator Inflation Rate & 0.52 & 0.71 & 0.69 & 0.59 & 0.50 & 0.47 & 0.46 & 0.39 & 0.11 & -0.18 \\
\hline Gasoline CPI Inflation Rate & 0.45 & 0.65 & 0.57 & 0.44 & 0.36 & 0.33 & 0.31 & 0.24 & -0.04 & -0.36 \\
\hline U.S. CPI Inflation Rate & 0.44 & 0.66 & 0.70 & 0.66 & 0.63 & 0.63 & 0.63 & 0.58 & 0.38 & 0.10 \\
\hline
\end{tabular}

Table 3: Forecast Accuracy Analysis (2001Q2 to 2015Q2)

\begin{tabular}{lccccc}
\hline \multicolumn{7}{l}{ Inflation Forecast Errors against relevant CPI inflation rate $\left(\pi_{t}\right)$} \\
\hline \\
\hline RMSE & $\mathrm{IEI}^{1}$ & Naïve & $\mathrm{IT}$ & $\mathrm{SPF}^{2}$ & $\mathrm{BCS}^{3}$ \\
MAE & 0.78 & 0.82 & 0.55 & 1.02 & 1.49 \\
\hline
\end{tabular}

Notes:

1- $\Pi_{\mathrm{t}}=$ average quarterly inflation rate over the past two years based on the CPI.

2- $\Pi_{\mathrm{t}}=$ year-over-year inflation rate based on the CPI; SPF: Survey of Professional Forecasters.

3- $\Pi_{t}=6$-month inflation rate (s.a.a.r.) based on the CPI; BCS: Business Confidence Survey. 


\begin{tabular}{cccc}
\hline & \multicolumn{3}{c}{$\pi_{\mathrm{t}}-\mathrm{E}_{\mathrm{t}-\mathrm{x}} \pi_{\mathrm{t}}=\alpha^{1}$} \\
\hline & $\mathrm{IEI}^{2}(\mathrm{x}=8)$ & $\operatorname{SPF}^{3}(\mathrm{x}=4)$ & $\mathrm{BCS}^{4}(\mathrm{x}=2)$ \\
\hline & & & \\
& $-0.32^{*}$ & 0.00 & -0.16 \\
Observations & $(0.16)$ & $(0.20)$ & $(0.22)$ \\
& 49 & 53 & 55 \\
\hline
\end{tabular}

Newey-West standard errors in parentheses

${ }^{* * *} p<0.01,{ }^{* *} p<0.05,{ }^{*} p<0.1$

Notes:

1- $\mathrm{X}=$ number of quarters of forecast horizon.

2- $\Pi_{t}=$ average quarterly inflation rate over the past two years based on the CPI.

3- $\Pi_{\mathrm{t}}=$ year-over-year inflation rate based on the CPI; SPF: Survey of Professional Forecasters.

4- $\Pi_{\mathrm{t}}=6$-month inflation rate (s.a.a.r.) based on the CPI; BCS: Business Confidence Survey.

Table 5: Test of Rationality - Full Exploitation of Forecast Information (2001Q2 to 2015Q2)

\begin{tabular}{|c|c|c|c|}
\hline & \multicolumn{3}{|c|}{$\pi_{t}-E_{t-x} \pi_{t}=\alpha+\beta^{\star} E_{t-x} \pi_{t}^{1}$} \\
\hline & $\mathrm{IEI}^{2}(\mathrm{x}=8)$ & $\operatorname{SPF}^{3}(x=4)$ & $\mathrm{BCS}^{4}(\mathrm{x}=2)$ \\
\hline \multirow[t]{2}{*}{$\beta$} & $-1.48^{* * *}$ & $-1.24^{* * *}$ & $-1.22^{\star *}$ \\
\hline & $(0.28)$ & $(0.30)$ & $(0.47)$ \\
\hline \multirow[t]{2}{*}{$\alpha$} & $2.90^{\star * *}$ & $2.35^{\star * *}$ & $2.27^{* *}$ \\
\hline & $(0.62)$ & $(0.62)$ & (1.04) \\
\hline Observations & 49 & 53 & 55 \\
\hline Adj. R-squared & 0.47 & 0.23 & 0.09 \\
\hline F statistic & $15.45^{\star * *}$ & $8.84^{* * *}$ & $4.68^{* *}$ \\
\hline
\end{tabular}

Newey-West standard errors in parentheses

${ }^{* * *} p<0.01,{ }^{* *} p<0.05,{ }^{*} p<0.1$

1 - $x=$ number of quarters of forecast horizon.

2- $\Pi_{\mathrm{t}}=$ average quarterly inflation rate over the past two years based on the CPI.

3- $\Pi_{t}=$ year-over-year inflation rate based on the CPI; SPF: Survey of Professional Forecasters.

4- $\Pi_{t}=6$-month inflation rate (s.a.a.r.) based on the CPI; BCS: Business Confidence Survey. 
Table 6: Test of Rationality- Full Exploitation of Macroeconomic Data (2001Q2 to 2015Q2)

\begin{tabular}{|c|c|c|c|}
\hline \multicolumn{4}{|c|}{$\pi_{t}-E_{t-x} \pi_{t}=\alpha+\beta^{*} E_{t-x} \pi_{t}+V^{*} \pi_{t-(x+1)}+\varphi^{*} i_{t-(x+1)}+\delta^{*} u_{t-(x+1)}{ }^{1}$} \\
\hline & $|E|^{2}(x=8)$ & $\operatorname{SPF}^{3}(\mathrm{x}=4)$ & $\operatorname{BCS}^{4}(x=2)$ \\
\hline \multirow[t]{2}{*}{$\beta$} & $-1.54^{* * *}$ & $-1.29^{* \star *}$ & $-0.97^{\star *}$ \\
\hline & $(0.26)$ & $(0.46)$ & $(0.39)$ \\
\hline \multirow[t]{2}{*}{ Y - Lagged Canadian Inflation Rate } & -0.092 & -0.14 & $-0.30^{* *}$ \\
\hline & $(0.14)$ & $(0.15)$ & $(0.12)$ \\
\hline \multirow[t]{2}{*}{$\varphi$ - Lagged Prime Interest Rate (\%) } & $0.35^{* * *}$ & $0.41^{* * *}$ & 0.37 \\
\hline & $(0.098)$ & $(0.14)$ & $(0.31)$ \\
\hline \multirow[t]{2}{*}{$\delta$ - Lagged Canadian Unemployment Rate (\%) } & $0.69^{* * *}$ & $0.95^{\star * *}$ & 0.80 \\
\hline & $(0.14)$ & $(0.34)$ & $(0.50)$ \\
\hline \multirow[t]{2}{*}{$\alpha$} & $-3.15^{\star *}$ & $-5.04^{* *}$ & -4.83 \\
\hline & $(1.17)$ & $(2.27)$ & $(4.64)$ \\
\hline Observations & 49 & 53 & 55 \\
\hline Adj. R-squared & 0.67 & 0.43 & 0.19 \\
\hline F statistic (joint significance test of $\gamma, \varphi$, and $\delta$ ) & $9.07^{\star \star \star}$ & $5.42^{* \star *}$ & $3.16^{\star \star}$ \\
\hline
\end{tabular}

Newey-West standard errors in parentheses

${ }^{* * *} p<0.01,{ }^{* *} p<0.05,{ }^{*} p<0.1$

1- $\mathrm{X}=$ number of quarters of forecast horizon.

2- $\Pi_{t}=$ average quarterly inflation rate over the past two years based on the CPI.

3- $\Pi_{t}=$ year-over-year inflation rate based on the CPI; Bank's Target Interest Rate instead of Prime Business Rate; SPF: Survey of Professional Forecasters.

4- $\pi_{\mathrm{t}}=6$-month inflation rate (s.a.a.r.) based on the CPI; BCS: Business Confidence Survey. 
Table 7: Test of Rationality - Persistence of Forecast Errors (2001Q2 to 2015Q2)

\begin{tabular}{cccc}
\hline \multicolumn{4}{c}{$\pi_{\mathrm{t}}-\mathrm{E}_{\mathrm{t}-\mathrm{x}} \pi_{\mathrm{t}}=\alpha+\beta^{*}\left(\pi_{\mathrm{t}-(\mathrm{x}+1)}-\mathrm{E}_{\mathrm{t}-\mathrm{y}} \pi_{\mathrm{t}-(\mathrm{x}+1))}\right.$} \\
\hline $\mathrm{IE|}^{2}(\mathrm{x}=8 ; \mathrm{y}=17)$ & $\operatorname{SPF}^{3}(\mathrm{x}=4 ; \mathrm{y}=9)$ & $\mathrm{BCS}^{4}(\mathrm{x}=2 ; \mathrm{y}=5)$ \\
\hline$\beta$ & $-0.33^{*}$ & $-0.26^{* * *}$ & $-0.31^{* * *}$ \\
$\alpha$ & $(0.17)$ & $(0.09)$ & $(0.11)$ \\
& $-0.47^{* * *}$ & -0.11 & -0.16 \\
Observations & $(0.16)$ & $(0.17)$ & $(0.22)$ \\
Adj. R-squared & 40 & & 52 \\
\hline
\end{tabular}

Newey-West standard errors in parentheses

${ }^{* * *} p<0.01,{ }^{* *} p<0.05,{ }^{*} p<0.1$

1- $X=$ number of quarters of forecast horizon; $y=$ number of quarters the previous forecast was made.

2- $\Pi_{t}=$ average quarterly inflation rate over the past two years based on the CPI.

3- $\Pi_{t}=$ year-over-year inflation rate based on the CPI; SPF: Survey of Professional Forecasters.

4- $\Pi_{\mathrm{t}}=6$-month inflation rate (s.a.a.r.) based on the CPI; BCS: Business Confidence Survey.

Table 8: Univariate Tests of Adaptive Expectations (2001Q2 to 2015Q2)

\begin{tabular}{|c|c|c|c|}
\hline \multirow[b]{2}{*}{$|E|_{t}=\alpha+\beta^{*} \pi_{t-1}$} & \multicolumn{3}{|c|}{ Inflation rate $\left(\pi_{t-1}\right)$ : } \\
\hline & 2-year avg. & $\mathrm{y} / \mathrm{y}$ & $\mathrm{q} / \mathrm{q}(\mathrm{SAAR})$ \\
\hline \multirow[t]{2}{*}{$\beta$} & $0.24^{\star \star *}$ & $0.15^{\star \star *}$ & $0.08^{\star \star \star}$ \\
\hline & $(0.08)$ & $(0.04)$ & $(0.02)$ \\
\hline \multirow[t]{2}{*}{$\alpha$} & $1.64^{\star \star *}$ & $1.83^{\star \star *}$ & $1.96^{\star \star *}$ \\
\hline & $(0.16)$ & $(0.10)$ & $(0.08)$ \\
\hline Observations & 57 & 57 & 57 \\
\hline Adj. R-squared & 0.14 & 0.13 & 0.20 \\
\hline
\end{tabular}

Newey-West standard errors in parentheses

${ }^{* * *} p<0.01,{ }^{* *} p<0.05,{ }^{*} p<0.1$ 


\begin{tabular}{|c|c|c|c|}
\hline \multicolumn{4}{|c|}{$Y_{t}=\alpha+\beta^{*} \pi t_{t-1}+\gamma^{*} i_{t}+\varphi^{*} i_{t-1}+\delta^{*} u_{t}+\mu^{*} u_{t-1}$} \\
\hline & $\mathrm{Y}=\mid \mathrm{IE|^{1 }}$ & $\mathrm{Y}=\mathrm{SPF}^{2}$ & $Y=\mathrm{BCS}^{3}$ \\
\hline \multirow[t]{2}{*}{$\beta$ - Lagged Canadian Inflation Rate } & $0.14^{\star *}$ & $0.30^{* * *}$ & 0.04 \\
\hline & $(0.059)$ & $(0.03)$ & $(0.03)$ \\
\hline \multirow[t]{2}{*}{ Y - Prime Interest Rate (\%) } & $0.39^{\star * *}$ & $0.27^{\star *}$ & $0.41^{* * *}$ \\
\hline & $(0.09)$ & $(0.11)$ & $(0.12)$ \\
\hline \multirow[t]{2}{*}{$\varphi$ - Lagged Prime Interest Rate (\%) } & $-0.23^{\star * *}$ & $-0.20^{*}$ & $-0.28^{\star \star *}$ \\
\hline & $(0.08)$ & $(0.11)$ & $(0.10)$ \\
\hline \multirow[t]{2}{*}{$\delta$ - Canadian Unemployment Rate (\%) } & $-0.30^{* *}$ & $-0.50^{\star *}$ & $-0.40^{\star \star \star}$ \\
\hline & $(0.11)$ & $(0.19)$ & $(0.11)$ \\
\hline \multirow[t]{2}{*}{$\mu$ - Lagged Canadian Unemployment Rate (\%) } & $0.30^{\star \star *}$ & $0.65^{\star * *}$ & $0.36^{\star \star *}$ \\
\hline & $(0.08)$ & $(0.19)$ & $(0.09)$ \\
\hline \multirow[t]{2}{*}{$\alpha$} & $1.19^{*}$ & 0.057 & $1.74^{\star \star *}$ \\
\hline & $(0.66)$ & $(0.56)$ & $(0.59)$ \\
\hline Observations & 57 & 57 & 57 \\
\hline Adj. R-squared & 0.62 & 0.69 & 0.50 \\
\hline F statistic (joint significance test of $\gamma, \varphi, \delta$, and $\mu$ ) & $37.23^{* * *}$ & $8.79^{* * *}$ & $15.47^{* * *}$ \\
\hline
\end{tabular}

Newey-West standard errors in parentheses

${ }^{* * *} p<0.01,{ }^{* *} p<0.05,{ }^{*} p<0.1$

1- $\Pi_{t}=$ average quarterly inflation rate over the past two years based on the CPI.

2- $\Pi_{t}=$ year-over-year inflation rate based on the CPI; Bank's Target Interest Rate instead of Prime Business Rate; SPF: Survey of Professional Forecasters.

3- $\pi_{t}=6$-month inflation rate (s.a.a.r.) based on the CPI; BCS: Business Confidence Survey. 


\begin{tabular}{|c|c|c|}
\hline & $(1)$ & $(2)$ \\
\hline$\beta$ - Lagged Canadian Inflation Rate (\%, 2-year avg.) & $\begin{array}{l}0.135^{* *} \\
(0.0670)\end{array}$ & \\
\hline$\beta$ - Canadian Inflation Rate (\%, 2-year avg.) & & $\begin{array}{c}0.222^{* * *} \\
(0.054)\end{array}$ \\
\hline$\mu$ - Lagged Canadian Unemployment Rate $(\%$, SA) & $\begin{array}{c}-0.115^{* * *} \\
(0.0422)\end{array}$ & $\begin{array}{c}-0.120 * * * \\
(0.043)\end{array}$ \\
\hline Y - Hourly Wages Outlook (Balance of Opinion) & $\begin{array}{c}0.006 * * * \\
(0.002)\end{array}$ & $\begin{array}{r}0.004^{* *} \\
(0.002)\end{array}$ \\
\hline$\varphi$ - Input Price Outlook (Balance of Opinion) & $\begin{array}{c}0.006 * * * \\
(0.001)\end{array}$ & $\begin{array}{c}0.006^{* * *} \\
(0.001)\end{array}$ \\
\hline$\delta$ - Crisis-Period/Post-Recession Indicator (after & & \\
\hline 2008Q3) & $\begin{array}{c}-0.309 * * * \\
(0.091)\end{array}$ & $\begin{array}{c}-0.252^{* * *} \\
(0.074)\end{array}$ \\
\hline$\omega$ - Lagged Growth Rate of WTI USD Price & $\begin{array}{l}0.003^{*} \\
(0.001)\end{array}$ & $\begin{array}{c}0.004^{* * *} \\
(0.001)\end{array}$ \\
\hline$\alpha$ & $\begin{array}{c}2.740 * * * \\
(0.330)\end{array}$ & $\begin{array}{c}2.591^{* * *} \\
(0.309)\end{array}$ \\
\hline Observations & 57 & 57 \\
\hline Adj. R-squared & 0.769 & 0.826 \\
\hline
\end{tabular}

Newey-West standard errors in parentheses

$* * * p<0.01, * * p<0.05, * p<0.1$ 
Table 11: Ordered Logit Regression from the Business Outlook Survey - 2001Q2 to 2015Q2

Dependent variable:

Firm-Level Inflation Expectations

\section{Odds Ratio}

Past Sales Conditions: Negative

$0.84^{* *}$

$(0.07)$

Past Sales Conditions: Positive

1.06

$(0.08)$

Past Sales: Decline

0.99

(0.09)

Some Difficulties

1.07

(0.07)

Significant Difficulties

$1.29^{* *}$

(0.14)

$1.17^{\star *}$

Labour Shortages

$(0.07)$

Wage Outlook: Negative

0.93

(0.08)

Wage Outlook: Positive

$1.32^{* \star *}$

$(0.09)$

Input Prices Outlook: Negative

1.02

$(0.08)$

Input Prices Outlook: Positive

$1.60^{\star * *}$

$(0.11)$

Input Prices: Decline

$0.77^{* * *}$

(0.08)

Output Prices Outlook: Negative

1.04

(0.08)

$1.14^{*}$

$(0.08)$

$0.76^{\star \star *}$

Output Prices: Decline

$(0.07)$

1.02

$(0.07)$

Large Firm ( $>=500$ employees)

$0.78^{\star \star \star}$

$(0.05)$

$1.04^{* *}$

Lagged Canadian Real GDP Growth (\%, q/q SAAR)

$(0.02)$

1.00

Lagged Canadian Unemployment Rate (\%, SA)

(0.06)

Lagged Canadian Inflation Rate (\%, 2-year avg.)

$1.12^{*}$

$(0.07)$

Lagged U.S. Real GDP Growth (\%, q/q SAAR)

1.01

(0.02)

$1.48^{* * *}$

Lagged Prime Interest Rate

(0.05)

Lagged Growth Rate of WTI price (\%, q/q)

$1.02^{\star \star \star}$

$(0.00)$ 
Table 11 (cont'd)

Observations $\quad 5,376$

Sector dummies $\quad$ YES

Region dummies $\quad$ YES

Quarter dummies $\quad$ YES

$\begin{array}{ll}\text { McFadden Pseudo- } R^{2} & 0.09\end{array}$

Model degrees of freedom $\quad 41$

Wald $\mathrm{Chi}^{2}$ test for overall model fit ( $\mathrm{p}$-value) 0

Log pseudolikelihood $\quad-5066$

\begin{tabular}{|c|c|}
\hline \multicolumn{2}{|c|}{ BOS Explanatory Variables Globally Significant: YES/NO ${ }^{1,2}$} \\
\hline Past Sales (3 DoF) & $\mathrm{YES}^{* \star *}$ \\
\hline Future Sales (3 DoF) & NO \\
\hline Some \& Significant Difficulties (2 DoF) & YES* \\
\hline Invest in M\&E (2 DoF) & NO \\
\hline Number of Employees (2 DoF) & NO \\
\hline Wage Outlook (2 DoF) & $\mathrm{YES}^{* * *}$ \\
\hline Input Prices (3 DoF) & $\mathrm{YES}^{* * *}$ \\
\hline Output Prices (3 DoF) & $\mathrm{YES}^{* * *}$ \\
\hline Firm Size (2 DoF) & $\mathrm{YES}^{* * *}$ \\
\hline
\end{tabular}

Robust standard errors in parentheses; ${ }^{* * *} p<0.01,{ }^{* *} p<0.05,{ }^{*} p<0.1$

Note: 1 . Wald Chi-Square tests. DoF=Degrees of Freedom.

2. The individual coefficients of BOS explanatory variables that are not jointly significant are not shown in the main table. 
Table 12: Base vs. "Structural Shift" Ordered Logit Regression from the Business Outlook Survey - 2001Q2 to 2015Q2

Dependent variable:

Firm-Level Inflation Expectations

\section{Base Model}

(1)

Since the Great Recession Indicator (after 2008Q3)

Input Prices Outlook: Negative

1.02

$(0.08)$

$1.60^{* * *}$

$(0.11)$

$0.77^{* * *}$

(0.08)

Structural Shift

(2)

$0.50^{* * *}$

1.09

$(0.11)$

$1.81^{* * *}$

$(0.18)$

0.98

(0.13)

Since the Great Recession
0.84

$(0.13)$

$0.79^{*}$

$(0.11)$

$0.61^{\star \star}$

(0.12)

1.04

0.88

(0.08)

(0.09)

$1.14^{*}$

$1.20^{*}$

(0.11)

(0.08)

$0.76^{\star \star *}$

(0.07)

0.84

(0.10)

Since the Great Recession
OP: Negative

OP: Positive

OP: Decline

Lagged Canadian Real GDP Growth (\%, q/q SAAR)

Lagged Canadian Unemployment Rate (\%, SA)

Lagged Canadian Inflation Rate (\%, 2-year avg.)

Lagged U.S. Real GDP Growth (\%, q/q SAAR)
$1.51^{* * *}$

$(0.23)$

0.93

$(0.13)$

$0.74^{*}$

(0.13)

$1.04^{\star *}$

$(0.02)$

1.00

(0.06)

$1.12^{*}$

(0.07)

1.01

(0.02)
$1.03^{*}$

$(0.02)$

$0.85^{\text {** }}$

(0.06)

1.06

(0.07)

0.99

(0.02) 
Table 12 (cont'd)

\begin{tabular}{lcc}
\hline Lagged Prime Interest Rate & $1.48^{\star * *}$ & 1.05 \\
& $(0.05)$ & $(0.06)$ \\
Lagged Growth Rate of WTI price (\%, q/q) & $1.02^{* * *}$ & $1.02^{* * *}$ \\
& $(0.00)$ & $(0.00)$ \\
\hline & & \\
Observations & 5,376 & 5,376 \\
Sector dummies & YES & YES \\
Region dummies & YES & YES \\
Quarter dummies & YES & YES \\
McFadden Pseudo-R ${ }^{2}$ & 0.089 & 0.098 \\
Model degrees of freedom & 41 & 65 \\
Wald Chi $^{2}$ test for overall model fit (p-value) & 0 & 0 \\
Log pseudolikelihood & -5066 & -5014 \\
\hline \multicolumn{2}{c}{ BOS Explanatory Variables Globally Significant: YES/NO,2 } \\
\hline
\end{tabular}

Overall Wald Chi ${ }^{2}$ significance test of interacted BOS variables

YES ${ }^{* * *}$

\begin{tabular}{|c|c|c|}
\hline $\begin{array}{l}\text { Past Sales ( } 3 \text { DoF) } \\
\text { Past Sales since the GR ( } 3 \text { DoF) }\end{array}$ & $\begin{array}{c}\text { YES }^{* * *} \\
-\end{array}$ & $\begin{array}{l}\text { YES* } \\
\text { NO }\end{array}$ \\
\hline Future Sales (3 DoF) & NO & NO \\
\hline Future Sales since the GR (3 DoF) & - & NO \\
\hline Some \& Significant difficulties (2 DoF) & YES* & YES** \\
\hline Some \& Significant difficulties since the GR (2 DoF) & - & NO \\
\hline Invest in M\&E (2 DoF) & NO & NO \\
\hline M\&E since the GR (2 DoF) & - & NO \\
\hline Number of employees (2 DoF) & NO & NO \\
\hline Number of employees since the GR (2 DoF) & - & NO \\
\hline Wage Outlook (2 DoF) & YES $S^{* * *}$ & YES* \\
\hline Wage Outlook since the GR (2 DoF) & - & NO \\
\hline Input Prices (3 DoF) & YES $S^{* * *}$ & YES*** \\
\hline Input Prices since the GR (3 DoF) & - & YES** \\
\hline Output Prices (3 DoF) & YES $^{* * *}$ & YES $S^{* * *}$ \\
\hline Output Prices since the GR (3 DoF) & - & YES $* *$ \\
\hline Firm Size (2 DoF) & $\mathrm{YES}^{* * *}$ & YES ** \\
\hline Firm Size since the GR (2 DoF) & - & NO \\
\hline
\end{tabular}

Robust standard errors in parentheses; *** $p<0.01,{ }^{* *} p<0.05,{ }^{*} p<0.1$

Note: 1 . Wald Chi-Square tests. DoF=Degrees of Freedom. GR $=$ Great Recession.

2. The coefficients of BOS explanatory variables are shown only when the coefficients of interacted BOS explanatory variables are jointly significant. 
Chart 1: Distribution of inflation expectations across firms, by quarter (2001Q2 to 2015Q2)

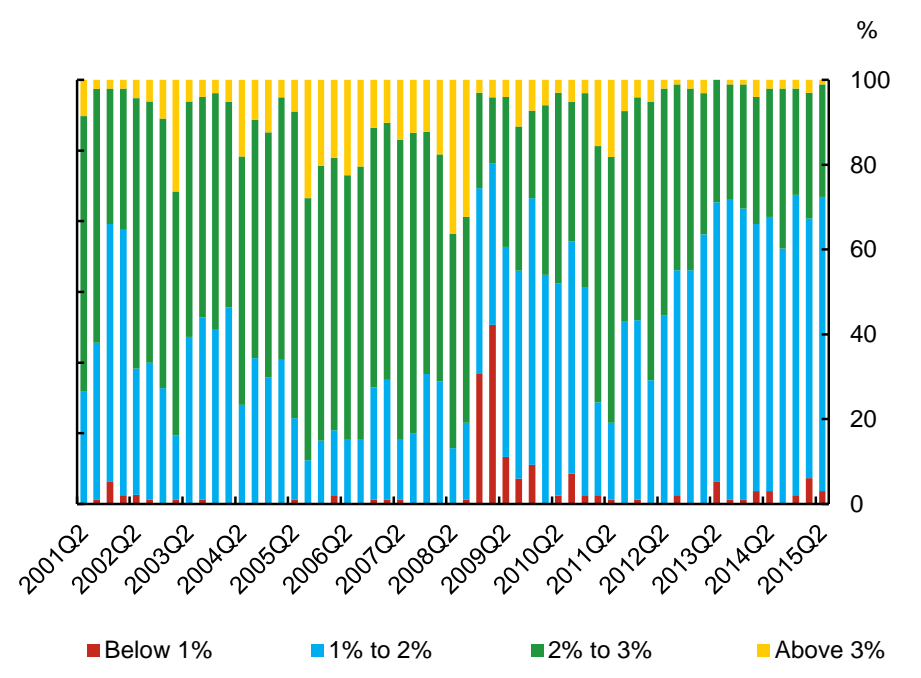

Last observation: 2015Q2

Chart 3: Measures of inflation expectations, by quarter (2001Q2 to 2015Q2)

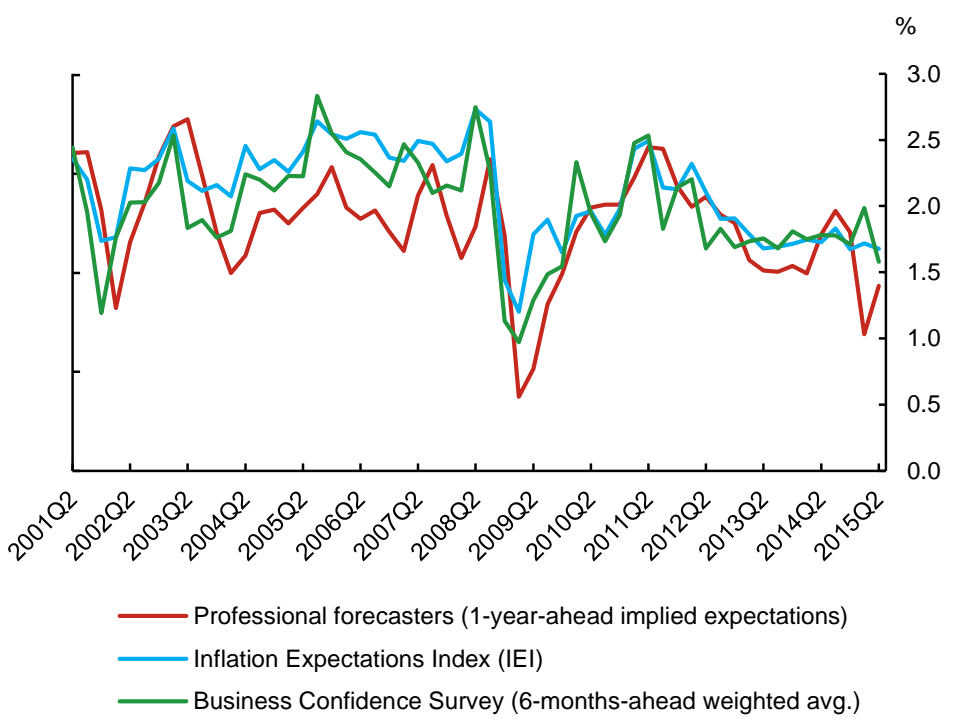

Last observation: 2015Q2
Chart 2: Comparing expectations and actual inflation, by quarter (2001Q2 to 2015Q2)

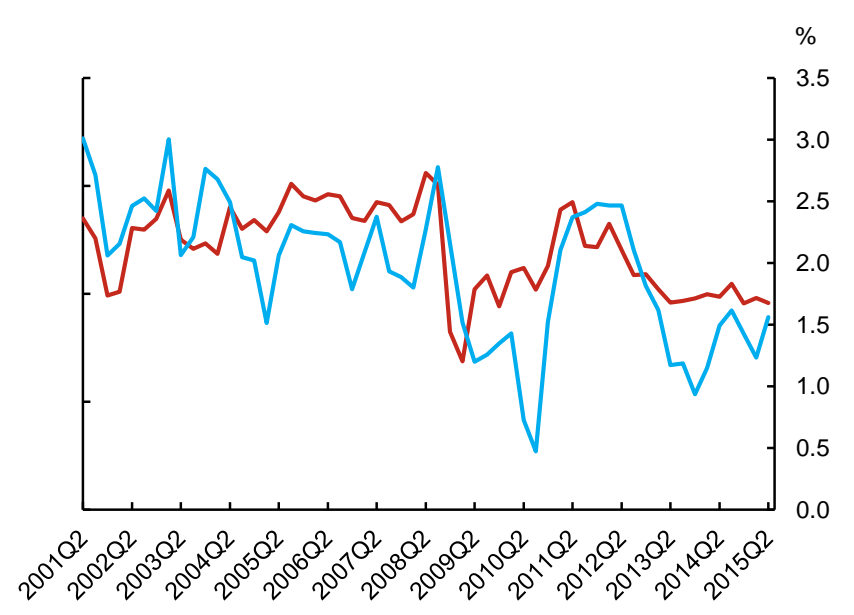

Inflation Expectations Index (IEI) — Headline CPI Inflation (2 yr avg.)

Last observation: 2015Q2

Chart 4: Inflation expectations index (IEI) forecast errors, by quarter (2003Q2 to 2015Q2)

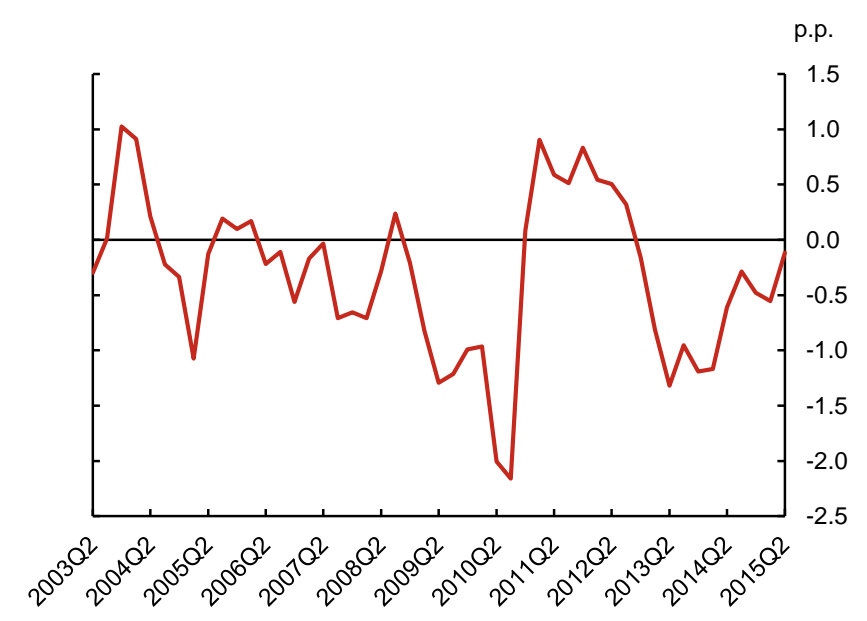

Last observation: 2015Q2 
Chart 5: Average of mean percentage probability estimates given to each range of future inflation (2014Q2 to 2015Q2)

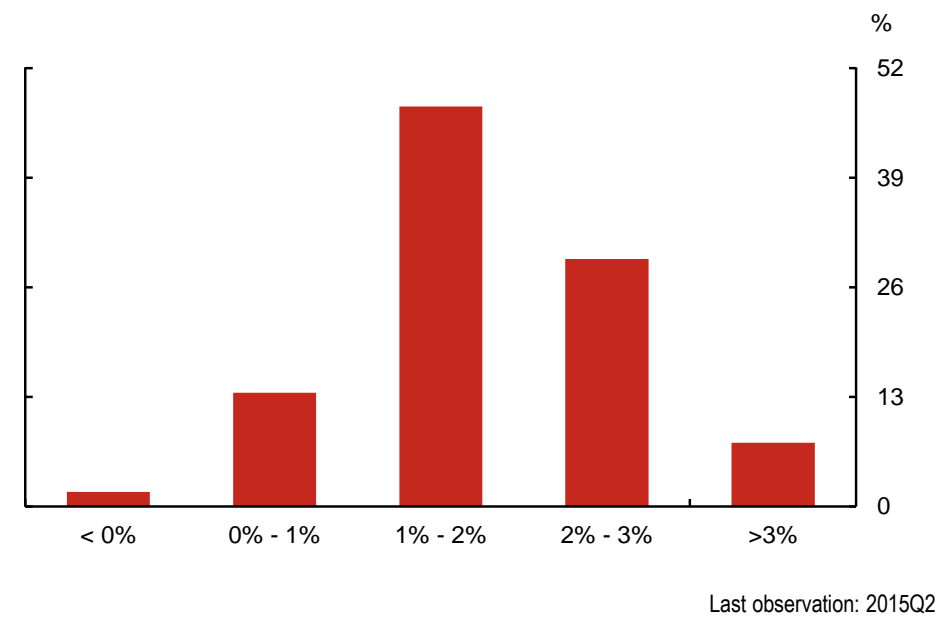




\section{Appendix A - An Overview of the BOS Variables Used in the Analyses}

Below is a description of the BOS explanatory variables that are included in the analyses (see also Martin and Papile 2004).

1) Business activity: The first question asks whether the change in the growth rate of sales volumes (i.e., adjusted for price changes) over the past 12 months was (i) greater, (ii) lesser or (iii) the same, compared with the preceding 12 months. Firms are also asked if their sales volumes declined over the past 12 months. Exactly the same question is asked about future sales volumes (i.e., over the next 12 months).

2) Investment and employment: Firms are asked if the level of investment spending on machinery and equipment over the next 12 months is expected to be: (i) higher, (ii) lower or (iii) the same, compared with the past 12 months. The same question is asked for the level of employment (full-time equivalent).

3) Capacity pressures: The first question is the following: "How would you rate the current ability of your firm to meet an unexpected increase in demand?" The firm can choose between: ) no difficulty) some difficulty; and 3) significant difficulty. The second question on capacity pressures asks firms whether they are facing labour shortages that restrict their ability to meet demand (yes/no).

4) Prices: BOS questions pertaining to the prices a firm pays for labour and inputs (other than labour) and charges for its output ask about the expected change, over the next 12 months, in the rate of increase of those prices. The possible answers are: (i) greater (e.g., $2 \%$ vs. $1 \%$ ); (ii) lesser; or (iii) the same rate. In the case of input and output prices, firms are also asked if they expect the average level of these to decline. 
Appendix B - Alternative Correlations

Table B1: Correlation Between BOS IEI and Various Inflation Indicators (\%, y-o-y; 2001Q2 to 2015Q2 - GDP deflator until 2015Q1)

\begin{tabular}{lrrrrrrrrrr}
\hline Measure of Inflation & $\pi_{t-1}$ & $\pi_{t}$ & $\pi_{t+1}$ & $\pi_{t+2}$ & $\pi_{t+3}$ & $\pi_{t+4}$ & $\pi_{t+5}$ & $\pi_{t+6}$ & $\pi_{t+7}$ & $\pi_{t+8}$ \\
\hline CPI Inflation Rate & 0.379 & 0.611 & 0.599 & 0.485 & 0.195 & -0.161 & -0.195 & -0.131 & -0.123 & -0.142 \\
Core CPI Inflation Rate & 0.098 & 0.061 & -0.011 & -0.059 & -0.117 & -0.292 & -0.350 & -0.338 & -0.393 & -0.385 \\
GDP Deflator Inflation Rate & 0.481 & 0.694 & 0.643 & 0.446 & 0.118 & -0.162 & -0.118 & 0.014 & 0.069 & 0.035 \\
Gasoline CPI Inflation Rate & 0.436 & 0.662 & 0.528 & 0.327 & 0.032 & -0.223 & -0.108 & 0.044 & 0.071 & 0.000 \\
U.S. CPI Inflation Rate & 0.488 & 0.750 & 0.765 & 0.638 & 0.377 & 0.122 & 0.104 & 0.179 & 0.197 & 0.117 \\
\hline
\end{tabular}


Appendix C - Alternative Dates of Crisis (Friedrich and Gosselin, 2015)

Table C1: Selected Models of Inflation Expectations - Alternative dates of crisis (Friedrich and Gosselin)

$$
I E I_{t}=\alpha+\beta^{*} \pi t-1(/ t)+\mu^{*} u_{t-1}+\gamma^{*} \text { wages }_{t}+\varphi^{*} \text { input }_{t-1}+\delta^{*} \text { crisis }_{t}+\omega^{*} W T I_{t-1}
$$

\begin{tabular}{|c|c|c|c|c|c|c|}
\hline \multirow{3}{*}{$\beta$ - Lagged Canadian Inflation Rate (\%, 2-year avg.) } & \multicolumn{2}{|c|}{ Crisis after $2007 Q 3$} & \multicolumn{2}{|c|}{ Crisis after $2009 Q 3$} & \multicolumn{2}{|c|}{ Crisis after 2011Q4 } \\
\hline & $0.155^{* *}$ & & $0.135^{* *}$ & & $0.156^{* * *}$ & \\
\hline & $(0.0705)$ & & $(0.0636)$ & & $(0.0521)$ & \\
\hline \multirow[t]{2}{*}{$\beta$ - Canadian Inflation Rate (\%, 2-year avg.) } & & $0.252 * * *$ & & $0.219 * * *$ & & $0.231 * * *$ \\
\hline & & $(0.0590)$ & & $(0.0505)$ & & $(0.0336)$ \\
\hline \multirow[t]{2}{*}{$\mu$ - Lagged Canadian Unemployment Rate $(\%, S A)$} & $-0.184 * * *$ & $-0.175^{* * *}$ & $-0.124 * * *$ & $-0.126 * * *$ & $-0.189 * * *$ & $-0.180 * * *$ \\
\hline & $(0.0450)$ & $(0.0373)$ & $(0.0363)$ & $(0.0368)$ & $(0.0330)$ & $(0.0289)$ \\
\hline \multirow[t]{2}{*}{ Y - Hourly Wages Outlook (Balance of Opinion) } & $0.00514^{* *}$ & $0.00326^{*}$ & $0.00938^{* * *}$ & $0.00728^{* * *}$ & $0.00941 * * *$ & $0.00727^{* * *}$ \\
\hline & $(0.00201)$ & $(0.00193)$ & $(0.00114)$ & $(0.00124)$ & $(0.00150)$ & $(0.00148)$ \\
\hline \multirow[t]{2}{*}{$\varphi$ - Input Price Outlook (Balance of Opinion) } & $0.00686^{* * *}$ & $0.00685^{* * *}$ & $0.00614^{* * *}$ & $0.00600^{* * *}$ & $0.00412^{* * *}$ & $0.00415^{* * *}$ \\
\hline & $(0.00124)$ & $(0.00111)$ & $(0.00131)$ & $(0.00103)$ & $(0.00100)$ & $(0.000788)$ \\
\hline \multirow[t]{2}{*}{$\delta$ - Crisis-Period/Post-Recession Indicator } & $-0.238 * * *$ & $-0.204 * * *$ & $-0.305^{* * *}$ & $-0.255^{* * *}$ & $-0.297 * * *$ & $-0.252 * * *$ \\
\hline & $(0.0718)$ & $(0.0533)$ & $(0.0722)$ & $(0.0604)$ & $(0.0666)$ & $(0.0532)$ \\
\hline \multirow[t]{2}{*}{$\omega$ - Lagged Growth Rate of WTI USD Price } & $0.00489 * * *$ & $0.00513^{* * *}$ & 0.00239 & $0.00307^{* *}$ & $0.00306^{* *}$ & $0.00370 * * *$ \\
\hline & $(0.00173)$ & $(0.00109)$ & $(0.00180)$ & $(0.00140)$ & $(0.00148)$ & $(0.00110)$ \\
\hline \multirow[t]{2}{*}{$\alpha$} & $3.174 * * *$ & $2.922 * * *$ & $2.745^{* * *}$ & $2.597^{* * *}$ & $3.118^{* * *}$ & $2.925^{* * *}$ \\
\hline & $(0.389)$ & $(0.296)$ & $(0.317)$ & $(0.284)$ & $(0.256)$ & $(0.228)$ \\
\hline Observations & 57 & 57 & 57 & 57 & 57 & 57 \\
\hline Adj. R-squared & 0.722 & 0.804 & 0.784 & 0.838 & 0.786 & 0.843 \\
\hline
\end{tabular}

Newey-West standard errors in parentheses

${ }^{* * *} p<0.01,{ }^{* *} p<0.05, * p<0.1$ 


\section{Appendix D - Different Models of BOS Firm-Level Inflation Expectations}

Table D1: Interval and Ordered Probit/Logit Regressions from the Business Outlook Survey - 2001Q2 to 2015Q2

Dependent variable:

Firm-Level Inflation Expectations

\begin{tabular}{|c|c|c|c|c|}
\hline \multirow[b]{3}{*}{ VARIABLES } & \multirow[b]{2}{*}{ Interval } & \multicolumn{3}{|c|}{ Ordered } \\
\hline & & Probit & Logit & Logit \\
\hline & $(1)$ & $(2)$ & (3) & (4) \\
\hline Past Sales Conditions: Negative & $\begin{array}{l}-0.0579 \\
(0.0354)\end{array}$ & $\begin{array}{c}-0.0971^{* *} \\
(0.0482)\end{array}$ & $\begin{array}{l}-0.176^{* *} \\
(0.0856)\end{array}$ & $\begin{array}{c}-0.160^{*} \\
(0.0856)\end{array}$ \\
\hline Past Sales Conditions: Positive & $\begin{array}{c}0.0436 \\
(0.0312)\end{array}$ & $\begin{array}{c}0.0404 \\
(0.0417)\end{array}$ & $\begin{array}{c}0.0561 \\
(0.0737)\end{array}$ & $\begin{array}{c}0.0149 \\
(0.0743)\end{array}$ \\
\hline Past Sales: Decline & $\begin{array}{r}-0.00258 \\
(0.0356)\end{array}$ & $\begin{array}{c}-0.00183 \\
(0.0489)\end{array}$ & $\begin{array}{c}-0.0126 \\
(0.0867)\end{array}$ & $\begin{array}{c}0.000304 \\
(0.0868)\end{array}$ \\
\hline Future Sales Outlook: Negative & $\begin{array}{l}-0.0605^{*} \\
(0.0335)\end{array}$ & $\begin{array}{c}-0.0939^{\star *} \\
(0.0445)\end{array}$ & $\begin{array}{l}-0.160^{\star *} \\
(0.0786)\end{array}$ & $\begin{array}{c}-0.141^{*} \\
(0.0795)\end{array}$ \\
\hline Future Sales Outlook: Positive & $\begin{array}{l}-0.0386 \\
(0.0315)\end{array}$ & $\begin{array}{l}-0.0600 \\
(0.0419)\end{array}$ & $\begin{array}{l}-0.0924 \\
(0.0738)\end{array}$ & $\begin{array}{l}-0.0575 \\
(0.0743)\end{array}$ \\
\hline Future Sales: Decline & $\begin{array}{r}-0.00261 \\
(0.0403)\end{array}$ & $\begin{array}{l}0.00573 \\
(0.0559)\end{array}$ & $\begin{array}{c}0.0253 \\
(0.1000)\end{array}$ & $\begin{array}{l}0.0222 \\
(0.101)\end{array}$ \\
\hline Some Difficulties & $\begin{array}{c}0.0344 \\
(0.0264)\end{array}$ & $\begin{array}{c}0.0410 \\
(0.0356)\end{array}$ & $\begin{array}{c}0.0654 \\
(0.0626)\end{array}$ & $\begin{array}{c}0.0603 \\
(0.0628)\end{array}$ \\
\hline Significant Difficulties & $\begin{array}{c}0.111^{* *} \\
(0.0487)\end{array}$ & $\begin{array}{c}0.146^{* *} \\
(0.0614)\end{array}$ & $\begin{array}{l}0.254^{* *} \\
(0.108)\end{array}$ & $\begin{array}{l}0.209^{*} \\
(0.109)\end{array}$ \\
\hline Invest in M\&E: Less & $\begin{array}{l}-0.0151 \\
(0.0318)\end{array}$ & $\begin{array}{l}-0.0326 \\
(0.0429)\end{array}$ & $\begin{array}{l}-0.0412 \\
(0.0762)\end{array}$ & $\begin{array}{c}-0.0173 \\
(0.0764)\end{array}$ \\
\hline Invest in M\&E: More & $\begin{array}{l}-0.0228 \\
(0.0266)\end{array}$ & $\begin{array}{l}-0.0271 \\
(0.0357)\end{array}$ & $\begin{array}{l}-0.0476 \\
(0.0630)\end{array}$ & $\begin{array}{l}-0.0498 \\
(0.0630)\end{array}$ \\
\hline Labour Shortages & $\begin{array}{l}0.0637^{\star *} \\
(0.0271)\end{array}$ & $\begin{array}{l}0.0889^{* *} \\
(0.0362)\end{array}$ & $\begin{array}{c}0.161^{* *} \\
(0.0638)\end{array}$ & $\begin{array}{c}0.143^{\star *} \\
(0.0641)\end{array}$ \\
\hline Number of Employees: Lower & $\begin{array}{l}-0.0252 \\
(0.0378)\end{array}$ & $\begin{array}{l}-0.0623 \\
(0.0528)\end{array}$ & $\begin{array}{c}-0.132 \\
(0.0929)\end{array}$ & $\begin{array}{c}-0.133 \\
(0.0939)\end{array}$ \\
\hline Number of Employees: Higher & $\begin{array}{c}0.0180 \\
(0.0256)\end{array}$ & $\begin{array}{c}0.0234 \\
(0.0347)\end{array}$ & $\begin{array}{c}0.0329 \\
(0.0613)\end{array}$ & $\begin{array}{c}0.0253 \\
(0.0616)\end{array}$ \\
\hline Wage Outlook: Negative & $\begin{array}{l}-0.0160 \\
(0.0347)\end{array}$ & $\begin{array}{l}-0.0413 \\
(0.0478)\end{array}$ & $\begin{array}{l}-0.0690 \\
(0.0858)\end{array}$ & $\begin{array}{c}-0.0985 \\
(0.0874)\end{array}$ \\
\hline Wage Outlook: Positive & $\begin{array}{l}0.113^{* * *} \\
(0.0286)\end{array}$ & $\begin{array}{l}0.153^{* * *} \\
(0.0375)\end{array}$ & $\begin{array}{l}0.275^{\star * *} \\
(0.0661)\end{array}$ & $\begin{array}{l}0.244^{\star * *} \\
(0.0665)\end{array}$ \\
\hline Input Prices Outlook: Negative & $\begin{array}{c}0.0337 \\
(0.0321)\end{array}$ & $\begin{array}{c}0.0222 \\
(0.0438)\end{array}$ & $\begin{array}{c}0.0244 \\
(0.0784)\end{array}$ & $\begin{array}{l}-0.0355 \\
(0.0787)\end{array}$ \\
\hline Input Prices Outlook: Positive & $\begin{array}{l}0.217^{\star * *} \\
(0.0297)\end{array}$ & $\begin{array}{l}0.269^{* * *} \\
(0.0392)\end{array}$ & $\begin{array}{l}0.473^{* * *} \\
(0.0690)\end{array}$ & $\begin{array}{l}0.458^{\star * *} \\
(0.0692)\end{array}$ \\
\hline Input Prices: Decline & $\begin{array}{c}-0.0915^{* *} \\
(0.0400)\end{array}$ & $\begin{array}{c}-0.153^{* * *} \\
(0.0555)\end{array}$ & $\begin{array}{c}-0.258^{* * *} \\
(0.0992)\end{array}$ & $\begin{array}{c}-0.258^{\star *} \\
(0.101)\end{array}$ \\
\hline Output Prices Outlook: Negative & $\begin{array}{c}0.0397 \\
(0.0313)\end{array}$ & $\begin{array}{c}0.0427 \\
(0.0425)\end{array}$ & $\begin{array}{c}0.0404 \\
(0.0752)\end{array}$ & $\begin{array}{c}0.0285 \\
(0.0752)\end{array}$ \\
\hline
\end{tabular}


Table D1 (cont'd)

\begin{tabular}{|c|c|c|c|c|}
\hline Output Prices Outlook: Positive & $\begin{array}{l}0.0694^{\star *} \\
(0.0292)\end{array}$ & $\begin{array}{l}0.0779^{* *} \\
(0.0392)\end{array}$ & $\begin{array}{c}0.133^{*} \\
(0.0689)\end{array}$ & $\begin{array}{c}0.133^{*} \\
(0.0691)\end{array}$ \\
\hline Output Prices: Decline & $\begin{array}{c}-0.0922^{* * *} \\
(0.0358)\end{array}$ & $\begin{array}{l}-0.159^{* * *} \\
(0.0494)\end{array}$ & $\begin{array}{l}-0.269^{* * *} \\
(0.0873)\end{array}$ & $\begin{array}{l}-0.323^{* * *} \\
(0.0883)\end{array}$ \\
\hline Small Firm (<100 employees) & $\begin{array}{c}0.0316 \\
(0.0313)\end{array}$ & $\begin{array}{c}0.0138 \\
(0.0413)\end{array}$ & $\begin{array}{c}0.0205 \\
(0.0735)\end{array}$ & $\begin{array}{c}0.0246 \\
(0.0734)\end{array}$ \\
\hline Large Firm (>=500 employees) & $\begin{array}{c}-0.110^{* * *} \\
(0.0267)\end{array}$ & $\begin{array}{c}-0.140^{* * *} \\
(0.0364)\end{array}$ & $\begin{array}{c}-0.242^{* * *} \\
(0.0644)\end{array}$ & $\begin{array}{c}-0.238^{* * *} \\
(0.0648)\end{array}$ \\
\hline Lagged Canadian Real GDP Growth (\%, q/q SAAR) & $\begin{array}{c}0.0130^{* *} \\
(0.00612)\end{array}$ & $\begin{array}{c}0.0167^{*} \\
(0.00871)\end{array}$ & $\begin{array}{l}0.0356^{\star *} \\
(0.0160)\end{array}$ & $\begin{array}{l}- \\
-\end{array}$ \\
\hline Lagged Canadian Unemployment Rate (\%, SA) & $\begin{array}{l}-0.0279 \\
(0.0256)\end{array}$ & $\begin{array}{l}0.00619 \\
(0.0349)\end{array}$ & $\begin{array}{c}0.000113 \\
(0.0620)\end{array}$ & - \\
\hline Lagged Canadian Inflation Rate (\%, 2-year avg.) & $\begin{array}{c}0.0214 \\
(0.0239)\end{array}$ & $\begin{array}{c}0.0536 \\
(0.0340)\end{array}$ & $\begin{array}{c}0.117^{\star} \\
(0.0604)\end{array}$ & $\begin{array}{l}- \\
-\end{array}$ \\
\hline Lagged U.S. Real GDP Growth (\%, q/q SAAR) & $\begin{array}{l}-0.00682 \\
(0.00647)\end{array}$ & $\begin{array}{c}0.00809 \\
(0.00883)\end{array}$ & $\begin{array}{c}0.0140 \\
(0.0159)\end{array}$ & - \\
\hline Lagged Prime Interest Rate & $\begin{array}{l}0.146^{* * *} \\
(0.0148)\end{array}$ & $\begin{array}{l}0.224^{* * *} \\
(0.0208)\end{array}$ & $\begin{array}{l}0.395^{* * *} \\
(0.0368)\end{array}$ & - \\
\hline Lagged Growth Rate of WTI price (\%, q/q) & $\begin{array}{c}0.0108^{* * *} \\
(0.000969)\end{array}$ & $\begin{array}{l}0.0145^{\star * *} \\
(0.00132)\end{array}$ & $\begin{array}{l}0.0249^{* * *} \\
(0.00238)\end{array}$ & $\begin{array}{l}- \\
-\end{array}$ \\
\hline Sector dummies & YES & YES & YES & YES \\
\hline Region dummies & YES & YES & YES & YES \\
\hline Quarter dummies & YES & YES & YES & YES \\
\hline Year dummies & NO & NO & NO & YES \\
\hline Number of observations & 5376 & 5376 & 5376 & 5376 \\
\hline Number of left-censored observations & 154 & - & - & - \\
\hline Number of uncensored observations & 0 & - & - & - \\
\hline Number of right-censored observations & 476 & - & - & - \\
\hline Number of interval observations & 4746 & - & - & - \\
\hline Log-likelihood of fitted model= & -6529 & -5067 & -5066 & -5011 \\
\hline Log-likelihood of model with just a constant= & -6977 & -5562 & -5562 & -5562 \\
\hline Pseudo-R-squared & 0.0642 & 0.0889 & 0.0891 & 0.0990 \\
\hline
\end{tabular}

Robust standard errors in parentheses; ${ }^{* * *} p<0.01,{ }^{* *} p<0.05,{ }^{*} p<0.1$ 
Table D2: Ordered Unconstrained vs. Constrained Logit Regressions from the Business Outlook Survey - 2001Q2 to 2015Q2

Dependent variable:

Firm-Level Inflation Expectations

Odds Ratio

\begin{tabular}{|c|c|c|}
\hline & \\
\hline & $\begin{array}{l}\text { "Declines" } \\
\text { Included }\end{array}$ & $\begin{array}{l}\text { "Declines" } \\
\text { NOT Included }\end{array}$ \\
\hline VARIABLES & $(1)$ & $(2)$ \\
\hline \multirow[t]{2}{*}{ Past Sales Conditions: Negative } & $0.838^{\star *}$ & $0.834^{\star *}$ \\
\hline & $(0.0717)$ & $(0.0659)$ \\
\hline \multirow[t]{2}{*}{ Past Sales Conditions: Positive } & 1.058 & 1.059 \\
\hline & $(0.0779)$ & $(0.0776)$ \\
\hline \multirow[t]{2}{*}{ Past Sales: Decline } & 0.988 & - \\
\hline & $(0.0856)$ & - \\
\hline \multirow[t]{2}{*}{ Future Sales Outlook: Negative } & $0.852^{* *}$ & $0.857^{* *}$ \\
\hline & $(0.0670)$ & $(0.0657)$ \\
\hline \multirow[t]{2}{*}{ Future Sales Outlook: Positive } & 0.912 & 0.899 \\
\hline & $(0.0673)$ & $(0.0632)$ \\
\hline \multirow[t]{2}{*}{ Future Sales: Decline } & 1.026 & - \\
\hline & $(0.103)$ & - \\
\hline \multirow[t]{2}{*}{ Some Difficulties } & 1.068 & 1.069 \\
\hline & $(0.0668)$ & $(0.0666)$ \\
\hline \multirow[t]{2}{*}{ Significant Difficulties } & $1.289^{\star *}$ & $1.304^{\star *}$ \\
\hline & $(0.140)$ & $(0.141)$ \\
\hline \multirow[t]{2}{*}{ Invest in M\&E: Less } & 0.960 & 0.953 \\
\hline & $(0.0731)$ & $(0.0722)$ \\
\hline \multirow[t]{2}{*}{ Invest in M\&E: More } & 0.953 & 0.953 \\
\hline & $(0.0600)$ & $(0.0600)$ \\
\hline \multirow[t]{2}{*}{ Labour Shortages } & $1.175^{\star \star}$ & $1.186^{\star * *}$ \\
\hline & $(0.0749)$ & $(0.0755)$ \\
\hline \multirow[t]{2}{*}{ Number of Employees: Lower } & 0.876 & $0.836^{\star *}$ \\
\hline & $(0.0814)$ & $(0.0762)$ \\
\hline \multirow[t]{2}{*}{ Number of Employees: Higher } & 1.033 & 1.032 \\
\hline & $(0.0634)$ & $(0.0631)$ \\
\hline \multirow[t]{2}{*}{ Wage Outlook: Negative } & 0.933 & 0.919 \\
\hline & $(0.0801)$ & $(0.0785)$ \\
\hline \multirow[t]{2}{*}{ Wage Outlook: Positive } & $1.317^{\star * *}$ & $1.317^{\star \star *}$ \\
\hline & $(0.0870)$ & $(0.0869)$ \\
\hline \multirow[t]{2}{*}{ Input Prices Outlook: Negative } & 1.025 & 0.953 \\
\hline & $(0.0803)$ & $(0.0703)$ \\
\hline \multirow[t]{2}{*}{ Input Prices Outlook: Positive } & $1.604^{\star * *}$ & $1.614^{\star * *}$ \\
\hline & $(0.111)$ & $(0.111)$ \\
\hline \multirow[t]{2}{*}{ Input Prices: Decline } & $0.772^{\star \star \star}$ & - \\
\hline & $(0.0766)$ & - \\
\hline \multirow[t]{2}{*}{ Output Prices Outlook: Negative } & 1.041 & 0.964 \\
\hline & $(0.0783)$ & $(0.0695)$ \\
\hline
\end{tabular}


Table D2 (cont'd)

\begin{tabular}{|c|c|c|}
\hline Output Prices Outlook: Positive & $\begin{array}{c}1.143^{*} \\
(0.0788)\end{array}$ & $\begin{array}{c}1.148^{* *} \\
(0.0790)\end{array}$ \\
\hline Output Prices: Decline & $\begin{array}{l}0.764^{* * *} \\
(0.0667)\end{array}$ & - \\
\hline Small Firm ( $<100$ employees) & $\begin{array}{c}1.021 \\
(0.0750)\end{array}$ & $\begin{array}{c}1.026 \\
(0.0754)\end{array}$ \\
\hline Large Firm (>=500 employees) & $\begin{array}{l}0.785^{* * *} \\
(0.0506)\end{array}$ & $\begin{array}{l}0.776^{* * *} \\
(0.0498)\end{array}$ \\
\hline Lagged Canadian Real GDP Growth (\%, q/q SAAR) & $\begin{array}{l}1.036^{* *} \\
(0.0165)\end{array}$ & $\begin{array}{l}1.040^{* *} \\
(0.0166)\end{array}$ \\
\hline Lagged Canadian Unemployment Rate $(\%, S A)$ & $\begin{array}{c}1.000 \\
(0.0620)\end{array}$ & $\begin{array}{c}0.995 \\
(0.0615)\end{array}$ \\
\hline Lagged Canadian Inflation Rate (\%, 2-year avg.) & $\begin{array}{c}1.124^{*} \\
(0.0679)\end{array}$ & $\begin{array}{c}1.123^{*} \\
(0.0681)\end{array}$ \\
\hline Lagged U.S. Real GDP Growth (\%, q/q SAAR) & $\begin{array}{c}1.014 \\
(0.0162)\end{array}$ & $\begin{array}{c}1.014 \\
(0.0161)\end{array}$ \\
\hline Lagged Prime Interest Rate & $\begin{array}{l}1.485^{\star \star *} \\
(0.0546)\end{array}$ & $\begin{array}{l}1.475^{\star * *} \\
(0.0542)\end{array}$ \\
\hline Lagged Growth Rate of WTI price (\%, q/q) & $\begin{array}{c}1.025^{\star * *} \\
(0.00244)\end{array}$ & $\begin{array}{c}1.025^{\star \star \star} \\
(0.00243)\end{array}$ \\
\hline $\begin{array}{l}\text { Sector dummies } \\
\text { Region dummies } \\
\text { Quarter dummies } \\
\text { Number of observations } \\
\text { Pseudo-R-squared } \\
\end{array}$ & $\begin{array}{l}\text { YES } \\
\text { YES } \\
\text { YES } \\
5376 \\
0.0891 \\
\end{array}$ & $\begin{array}{c}\text { YES } \\
\text { YES } \\
\text { YES } \\
5376 \\
0.0869 \\
\end{array}$ \\
\hline \multicolumn{3}{|c|}{ Equality of Effects of BOS variables: YES/NO ${ }^{1}$} \\
\hline Overall Test of Equality of Effects - All variables & $\mathrm{NO}^{* * *}$ & $\mathrm{NO}^{* \star *}$ \\
\hline Overall Test of Equality of Effects - Without Size \& Difficulties var. ${ }^{2}$ & $\mathrm{NO}^{* * *}$ & $N O^{* * *}$ \\
\hline Past Sales: Negative $=-($ Positive $)$ & YES & YES \\
\hline Future Sales: Negative $=-($ Positive $)$ & $\mathrm{NO}^{*}$ & $\mathrm{NO} * *$ \\
\hline Some $=$ Significant difficulties ${ }^{2}$ & $\mathrm{NO}^{*}$ & $\mathrm{NO} *$ \\
\hline Invest in M\&E: Negative $=-($ Positive $)$ & YES & YES \\
\hline Number of employees: Negative $=-($ Positive $)$ & YES & YES \\
\hline Wage Outlook: Negative $=-($ Positive $)$ & $\mathrm{NO}^{*}$ & YES \\
\hline Input Prices: Negative = - (Positive) & $\mathrm{NO}^{* * *}$ & $\mathrm{NO}^{* * *}$ \\
\hline Output Prices: Negative $=-$ (Positive) & YES & YES \\
\hline Firm Size: Small $=$ Large $^{2}$ & $\mathrm{NO}^{\star \star *}$ & $\mathrm{NO}^{* * *}$ \\
\hline
\end{tabular}

Robust standard errors in parentheses; ${ }^{* * *} p<0.01,{ }^{* *} p<0.05,{ }^{*} p<0.1$

Notes: 1. Wald Chi-Square tests.

2- Constraints : Firm Size: Small = Large and Some = Significant difficulties not

included in overall test 
Table D3: Base vs. "Structural Shift" Ordered Logit Regressions from the Business Outlook Survey - 2001Q2 to 2015Q2

\begin{tabular}{|c|c|c|c|c|c|c|}
\hline \multirow[b]{2}{*}{ Specification } & \multirow{2}{*}{$\begin{array}{c}\begin{array}{c}\text { Base } \\
\text { Model }\end{array} \\
(1)\end{array}$} & \multicolumn{5}{|c|}{ Structural Shift Models } \\
\hline & & $\begin{array}{c}(2) \\
>2008 Q 3\end{array}$ & $\begin{array}{c}(3) \\
>2008 Q 3\end{array}$ & $\begin{array}{c}(4) \\
>2007 Q 3\end{array}$ & $\begin{array}{c}(5) \\
>2009 Q 4\end{array}$ & $\begin{array}{c}(6) \\
>2011 Q 4\end{array}$ \\
\hline cession Indicator & - & $\begin{array}{c}0.497^{\star * *} \\
(0.115)\end{array}$ & $\begin{array}{l}0.467^{\star \star *} \\
(0.0674)\end{array}$ & $\begin{array}{l}0.484^{* * *} \\
(0.0483)\end{array}$ & $\begin{array}{c}0.731^{\star *} \\
(0.0944)\end{array}$ & $\begin{array}{l}0.446^{* * *} \\
(0.0564)\end{array}$ \\
\hline ns: Negative & $\begin{array}{c}0.838^{\star *} \\
(0.0717)\end{array}$ & $\begin{array}{c}0.889 \\
(0.106)\end{array}$ & $\begin{array}{c}0.838^{\star *} \\
(0.0722)\end{array}$ & $\begin{array}{l}0.826^{\star \star} \\
(0.0711)\end{array}$ & $\begin{array}{c}0.838^{* *} \\
(0.0718)\end{array}$ & $\begin{array}{c}0.835^{\star *} \\
(0.0718)\end{array}$ \\
\hline ns: Positive & $\begin{array}{c}1.058 \\
(0.0779)\end{array}$ & $\begin{array}{l}1.180^{*} \\
(0.118)\end{array}$ & $\begin{array}{c}1.065 \\
(0.0787)\end{array}$ & $\begin{array}{c}1.041 \\
(0.0770)\end{array}$ & $\begin{array}{c}1.055 \\
(0.0777)\end{array}$ & $\begin{array}{c}1.034 \\
(0.0765)\end{array}$ \\
\hline & $\begin{array}{c}0.988 \\
(0.0856)\end{array}$ & $\begin{array}{c}1.150 \\
(0.138)\end{array}$ & $\begin{array}{c}0.987 \\
(0.0863)\end{array}$ & $\begin{array}{c}0.993 \\
(0.0866)\end{array}$ & $\begin{array}{c}0.984 \\
(0.0855)\end{array}$ & $\begin{array}{c}0.991 \\
(0.0860)\end{array}$ \\
\hline
\end{tabular}

Since the Great Recession

\begin{tabular}{|c|c|c|c|c|c|c|}
\hline \multirow[t]{2}{*}{ PS: Negative } & - & 0.891 & - & - & - & - \\
\hline & - & $(0.152)$ & - & - & - & - \\
\hline \multirow[t]{2}{*}{ PS: Positive } & - & 0.810 & - & - & - & - \\
\hline & - & $(0.120)$ & - & - & - & - \\
\hline \multirow[t]{2}{*}{ PS: Decline } & - & $0.720^{*}$ & - & - & - & - \\
\hline & - & $(0.126)$ & - & - & - & - \\
\hline \multirow[t]{2}{*}{ Future Sales Outlook: Negative } & $0.852^{* *}$ & 0.863 & $0.862^{*}$ & $0.855^{\star *}$ & $0.857^{*}$ & $0.860^{*}$ \\
\hline & $(0.0670)$ & $(0.0899)$ & $(0.0680)$ & $(0.0676)$ & $(0.0674)$ & $(0.0680)$ \\
\hline \multirow[t]{2}{*}{ Future Sales Outlook: Positive } & 0.912 & $0.830^{\star}$ & 0.914 & 0.909 & 0.911 & 0.911 \\
\hline & $(0.0673)$ & $(0.0815)$ & $(0.0678)$ & $(0.0672)$ & $(0.0673)$ & $(0.0674)$ \\
\hline \multirow[t]{2}{*}{ Future Sales: Decline } & 1.026 & 0.991 & 1.075 & 1.022 & 1.033 & 0.998 \\
\hline & $(0.103)$ & $(0.138)$ & $(0.108)$ & $(0.103)$ & $(0.103)$ & $(0.100)$ \\
\hline \multicolumn{7}{|l|}{ Since the Great Recession } \\
\hline \multirow[t]{2}{*}{ FS: Negative } & - & 1.000 & - & - & - & - \\
\hline & - & $(0.160)$ & - & - & - & - \\
\hline \multirow[t]{2}{*}{ FS: Positive } & - & 1.240 & - & - & - & - \\
\hline & - & $(0.186)$ & - & - & - & - \\
\hline \multirow[t]{2}{*}{ FS: Decline } & - & 1.174 & - & - & - & - \\
\hline & - & $(0.237)$ & - & - & - & - \\
\hline \multirow[t]{2}{*}{ Some Difficulties } & 1.068 & $1.214^{* *}$ & 1.081 & 1.069 & 1.077 & 1.082 \\
\hline & $(0.0668)$ & $(0.104)$ & $(0.0681)$ & $(0.0673)$ & $(0.0675)$ & $(0.0680)$ \\
\hline \multirow[t]{2}{*}{ Significant Difficulties } & $1.289^{\star \star}$ & $1.432^{\star \star *}$ & $1.296^{\star *}$ & $1.239^{\star *}$ & $1.280^{\star \star}$ & $1.253^{* *}$ \\
\hline & $(0.140)$ & $(0.193)$ & $(0.142)$ & $(0.134)$ & $(0.139)$ & $(0.137)$ \\
\hline
\end{tabular}

Since the Great Recession

$\begin{array}{lcc}\text { Difficulties : Some } & - & 0.793^{\star} \\ & - & (0.0989) \\ \text { Difficulties : Significant } & - & 0.792 \\ & - & (0.178)\end{array}$


Table D3 (cont'd)

Invest in M\&E: Less

$\begin{array}{cccccc}0.960 & 0.878 & 0.969 & 0.977 & 0.957 & 0.980 \\ (0.0731) & (0.0911) & (0.0743) & (0.0749) & (0.0731) & (0.0750) \\ 0.953 & 0.910 & 0.957 & 0.952 & 0.962 & 0.964 \\ (0.0600) & (0.0785) & (0.0606) & (0.0601) & (0.0606) & (0.0609)\end{array}$

Since the Great Recession

\begin{tabular}{|c|c|c|c|c|c|c|}
\hline \multirow[t]{2}{*}{ M\&E: Less } & - & 1.226 & - & - & - & - \\
\hline & - & $(0.189)$ & - & - & - & - \\
\hline \multirow[t]{2}{*}{ M\&E: More } & - & 1.109 & - & - & - & - \\
\hline & - & $(0.141)$ & - & - & - & - \\
\hline \multirow[t]{2}{*}{ Labour Shortages } & $1.175^{\star \star}$ & 1.137 & $1.132^{*}$ & $1.191^{* * *}$ & $1.158^{* \star}$ & $1.185^{\star * *}$ \\
\hline & $(0.0749)$ & $(0.0930)$ & $(0.0729)$ & $(0.0768)$ & $(0.0741)$ & $(0.0760)$ \\
\hline \multirow[t]{2}{*}{ Number of Employees: Lower } & 0.876 & 0.968 & 0.863 & 0.893 & 0.878 & 0.892 \\
\hline & $(0.0814)$ & $(0.122)$ & $(0.0803)$ & $(0.0834)$ & $(0.0817)$ & $(0.0834)$ \\
\hline \multirow[t]{2}{*}{ Number of Employees: Higher } & 1.033 & 1.017 & 1.037 & 1.035 & 1.033 & 1.036 \\
\hline & $(0.0634)$ & $(0.0859)$ & $(0.0642)$ & $(0.0639)$ & $(0.0635)$ & $(0.0638)$ \\
\hline \multicolumn{7}{|l|}{ Since the Great Recession } \\
\hline \multirow[t]{2}{*}{ Labour Shortages } & - & 1.003 & - & - & - & - \\
\hline & - & $(0.134)$ & - & - & - & - \\
\hline \multirow[t]{2}{*}{ Employees: Lower } & - & 0.794 & - & - & - & - \\
\hline & - & $(0.149)$ & - & - & - & - \\
\hline \multirow[t]{2}{*}{ Employees: Higher } & - & 1.041 & - & - & - & - \\
\hline & - & $(0.129)$ & - & - & - & - \\
\hline \multirow[t]{2}{*}{ Wage Outlook: Negative } & 0.933 & 1.019 & 0.960 & 0.907 & 0.933 & 0.896 \\
\hline & $(0.0801)$ & $(0.127)$ & $(0.0830)$ & $(0.0787)$ & $(0.0803)$ & $(0.0776)$ \\
\hline \multirow[t]{2}{*}{ Wage Outlook: Positive } & $1.317^{* * *}$ & $1.230^{* *}$ & $1.328^{* * *}$ & $1.296^{\star * *}$ & $1.324^{\star * *}$ & $1.296^{\star \star \star}$ \\
\hline & $(0.0870)$ & $(0.107)$ & $(0.0884)$ & $(0.0862)$ & $(0.0877)$ & $(0.0860)$ \\
\hline \multicolumn{7}{|l|}{ Since the Great Recession } \\
\hline \multirow[t]{2}{*}{ Wage: Negative } & - & 0.902 & - & - & - & - \\
\hline & - & $(0.156)$ & - & - & - & - \\
\hline \multirow[t]{2}{*}{ Wage: Positive } & - & 1.175 & - & - & - & - \\
\hline & - & $(0.155)$ & - & - & - & - \\
\hline \multirow[t]{2}{*}{ Input Prices Outlook: Negative } & 1.025 & 1.087 & 1.095 & 1.127 & 1.084 & 0.991 \\
\hline & $(0.0803)$ & $(0.114)$ & $(0.115)$ & $(0.121)$ & $(0.111)$ & $(0.0914)$ \\
\hline \multirow[t]{2}{*}{ Input Prices Outlook: Positive } & $1.604^{* * *}$ & $1.809^{\star \star *}$ & $1.790^{\star * *}$ & $1.793^{\star * *}$ & $1.803^{* * *}$ & $1.692^{\star * *}$ \\
\hline & $(0.111)$ & $(0.176)$ & $(0.174)$ & $(0.180)$ & $(0.173)$ & $(0.141)$ \\
\hline \multirow[t]{2}{*}{ Input Prices: Decline } & $0.772^{* * *}$ & 0.978 & 0.987 & 1.010 & $0.785^{\star}$ & $0.724^{* * *}$ \\
\hline & $(0.0766)$ & $(0.129)$ & $(0.130)$ & $(0.139)$ & $(0.101)$ & $(0.0839)$ \\
\hline \multicolumn{7}{|l|}{ Since the Great Recession } \\
\hline \multirow[t]{2}{*}{ IP: Negative } & - & 0.844 & 0.833 & $0.773^{*}$ & 0.859 & 0.985 \\
\hline & - & $(0.134)$ & $(0.131)$ & $(0.118)$ & $(0.134)$ & $(0.170)$ \\
\hline \multirow[t]{2}{*}{ IP: Positive } & - & $0.793^{*}$ & $0.795^{\star}$ & $0.778^{*}$ & $0.769^{*}$ & $0.724^{* *}$ \\
\hline & - & $(0.110)$ & $(0.110)$ & $(0.102)$ & $(0.106)$ & $(0.106)$ \\
\hline \multirow[t]{2}{*}{ IP: Decline } & - & $0.611^{* *}$ & $0.597^{\star *}$ & $0.597^{* * *}$ & 0.961 & 1.337 \\
\hline & - & $(0.124)$ & $(0.120)$ & $(0.119)$ & $(0.189)$ & $(0.294)$ \\
\hline Output Prices Outlook: Negative & $\begin{array}{c}1.041 \\
(0.0783)\end{array}$ & $\begin{array}{c}0.878 \\
(0.0885)\end{array}$ & $\begin{array}{c}0.885 \\
(0.0890)\end{array}$ & $\begin{array}{c}0.826^{*} \\
(0.0853)\end{array}$ & $\begin{array}{c}0.842^{*} \\
(0.0837)\end{array}$ & $\begin{array}{c}0.937 \\
(0.0838)\end{array}$ \\
\hline
\end{tabular}


Table D3 (cont'd)

\begin{tabular}{lcccccc}
\hline Output Prices Outlook: Positive & $1.143^{*}$ & $1.197^{\star}$ & $1.203^{*}$ & $1.203^{*}$ & 1.093 & 1.098 \\
& $(0.0788)$ & $(0.114)$ & $(0.114)$ & $(0.119)$ & $(0.103)$ & $(0.0909)$ \\
Output Prices: Decline & $0.764^{\star * \star}$ & 0.839 & 0.854 & 0.876 & $0.807^{*}$ & $0.724^{* \star *}$ \\
& $(0.0667)$ & $(0.0960)$ & $(0.0975)$ & $(0.101)$ & $(0.0915)$ & $(0.0744)$
\end{tabular}

Since the Great Recession

\begin{tabular}{|c|c|c|c|c|c|c|}
\hline OP: Negative & - & $\begin{array}{c}1.510^{\star * *} \\
(0.228)\end{array}$ & $\begin{array}{c}1.489^{\star \star *} \\
(0.224)\end{array}$ & $\begin{array}{c}1.547^{\star \star *} \\
(0.224)\end{array}$ & $\begin{array}{c}1.714^{\star * *} \\
(0.255)\end{array}$ & $\begin{array}{l}1.428^{\star *} \\
(0.227)\end{array}$ \\
\hline \multirow[t]{2}{*}{ OP: Positive } & - & 0.935 & 0.936 & 0.916 & 1.112 & 1.099 \\
\hline & - & $(0.130)$ & $(0.128)$ & $(0.119)$ & $(0.151)$ & $(0.162)$ \\
\hline \multirow[t]{2}{*}{ OP: Decline } & - & $0.738^{*}$ & $0.717^{\star}$ & $0.710^{* \star}$ & 0.826 & 1.127 \\
\hline & - & $(0.131)$ & $(0.126)$ & $(0.122)$ & $(0.143)$ & $(0.209)$ \\
\hline \multirow[t]{2}{*}{ Small Firm (<100 employees) } & 1.021 & 0.969 & 1.024 & 1.017 & 1.015 & 1.014 \\
\hline & $(0.0750)$ & $(0.0977)$ & $(0.0756)$ & $(0.0749)$ & $(0.0747)$ & $(0.0746)$ \\
\hline \multirow[t]{2}{*}{ Large Firm (>=500 employees) } & $0.785^{\star * \star}$ & $0.802^{* *}$ & $0.774^{* * *}$ & $0.769^{\star * *}$ & $0.773^{\star \star *}$ & $0.772^{* * *}$ \\
\hline & $(0.0506)$ & $(0.0714)$ & $(0.0503)$ & $(0.0500)$ & $(0.0501)$ & $(0.0501)$ \\
\hline \multicolumn{7}{|l|}{ Since the Great Recession } \\
\hline \multirow[t]{2}{*}{ Small firm } & - & 1.116 & - & - & - & - \\
\hline & - & $(0.163)$ & - & - & - & - \\
\hline \multirow[t]{2}{*}{ Large firm } & - & 0.927 & - & - & - & - \\
\hline & - & $(0.121)$ & - & - & - & - \\
\hline \multirow[t]{2}{*}{ Lagged Canadian Real GDP Growth (\%, q/q SAAR) } & $1.036^{\star \star}$ & $1.027^{*}$ & $1.027^{*}$ & 0.999 & $1.047^{\star \star *}$ & 0.999 \\
\hline & $(0.0165)$ & $(0.0167)$ & $(0.0166)$ & $(0.0167)$ & $(0.0166)$ & $(0.0166)$ \\
\hline \multirow[t]{2}{*}{ Lagged Canadian Unemployment Rate (\%, SA) } & 1.000 & $0.849^{* *}$ & $0.855^{\star \star}$ & $0.663^{* * *}$ & 0.966 & $0.693^{\star * *}$ \\
\hline & $(0.0620)$ & $(0.0569)$ & $(0.0570)$ & $(0.0552)$ & $(0.0640)$ & $(0.0571)$ \\
\hline \multirow[t]{2}{*}{ Lagged Canadian Inflation Rate (\%, 2-year avg.) } & $1.124^{*}$ & 1.058 & 1.052 & $1.165^{\star \star}$ & 1.078 & $1.210^{* * *}$ \\
\hline & $(0.0679)$ & $(0.0661)$ & $(0.0654)$ & $(0.0737)$ & $(0.0658)$ & $(0.0753)$ \\
\hline \multirow[t]{2}{*}{ Lagged U.S. Real GDP Growth (\%, q/q SAAR) } & 1.014 & 0.993 & 0.993 & $1.061^{* * *}$ & 1.017 & $1.070^{* * *}$ \\
\hline & $(0.0162)$ & $(0.0162)$ & $(0.0161)$ & $(0.0182)$ & $(0.0162)$ & $(0.0181)$ \\
\hline \multirow[t]{2}{*}{ Lagged Prime Interest Rate } & $1.485^{\star \star \star}$ & 1.054 & 1.060 & 1.084 & $1.363^{\star \star \star}$ & $1.138^{* *}$ \\
\hline & $(0.0546)$ & $(0.0637)$ & $(0.0639)$ & $(0.0618)$ & $(0.0724)$ & $(0.0619)$ \\
\hline \multirow[t]{3}{*}{ Lagged Growth Rate of WTI price (\%, q/q) } & $1.025^{\star * *}$ & $1.023^{\star * *}$ & $1.023^{\star * *}$ & $1.023^{* * *}$ & $1.024^{* * *}$ & $1.022^{* * *}$ \\
\hline & $(0.00244$ & & & $(0.00251$ & $(0.00250$ & $(0.00251$ \\
\hline & ) & $(0.00248)$ & $(0.00247)$ & ) & ) & ) \\
\hline Observations & 5,376 & 5,376 & 5,377 & 5,376 & 5,376 & 5,376 \\
\hline Sector dummies & YES & YES & YES & YES & YES & YES \\
\hline Region dummies & YES & YES & YES & YES & YES & YES \\
\hline Quarter dummies & YES & YES & YES & YES & YES & YES \\
\hline Pseudo-R-squared & 0.0891 & 0.0985 & 0.0967 & 0.0975 & 0.0914 & 0.0906 \\
\hline Model degrees of freedom & 41 & 65 & 48 & 48 & 48 & 48 \\
\hline Significance of model chi2 test ( $p$-value) & 0 & 0 & 0 & 0 & 0 & 0 \\
\hline \multirow[t]{2}{*}{ Log pseudolikelihood } & -5066 & -5014 & -5024 & -5020 & -5054 & -5058 \\
\hline & bouch & Ilv Sianif & nt: YES/ & & & \\
\hline
\end{tabular}

Overall significance test of ALL interacted BOS variables

YES ${ }^{* * *}$

\begin{tabular}{|c|c|c|c|c|c|c|}
\hline Past Sales (3 DoF) & $\mathrm{YES}^{* * *}$ & YES $^{*}$ & $\mathrm{YES}^{* * *}$ & $\mathrm{YES}^{* * *}$ & $\mathrm{YES}^{* * *}$ & YES*** \\
\hline Past Sales since the GR (3 DoF) & - & NO & - & - & - & - \\
\hline Future Sales (3 DoF) & NO & NO & NO & NO & NO & NO \\
\hline
\end{tabular}


Table D3 (cont'd)

Future Sales since the GR (3 DoF)

Some \& serious difficulties (2 DoF)

Some \& significant difficulties since the GR (2 DoF)

Invest in M\&E (2 DoF)

M\&E since the GR (2 DoF)

Number of employees (2 DoF)

Number of employees since the GR (2 DoF)

Wage Outlook (2 DoF)

Wage since the GR (2 DoF)

Input Prices (3 DoF)

Input Prices since the GR (3 DoF)

Output Prices (3 DoF)

Output Prices since the GR (3 DoF)

Firm Size (2 DoF)

Firm Size since the GR (2 DoF)

\begin{tabular}{|c|c|c|c|c|c|}
\hline- & NO & - & - & - & - \\
\hline YES* & YES $^{* *}$ & YES* & YES* & YES* & YES* \\
\hline - & NO & - & - & - & - \\
\hline NO & NO & NO & NO & NO & NO \\
\hline- & NO & - & - & - & - \\
\hline NO & NO & NO & NO & NO & NO \\
\hline- & NO & - & - & - & - \\
\hline YES $S^{* * *}$ & YES* & YES $S^{* * *}$ & YES $^{* * *}$ & YES $^{* * *}$ & YES $S^{* \star *}$ \\
\hline- & NO & - & - & - & - \\
\hline YES*** & YES ${ }^{* * *}$ & YES $S^{\star * *}$ & $\mathrm{YES}^{* * *}$ & $\mathrm{YES}^{* * *}$ & YES $^{* * *}$ \\
\hline - & YES $^{* *}$ & YES ${ }^{* * *}$ & $\mathrm{YES}^{* * *}$ & NO & NO \\
\hline YES $S^{* * *}$ & YES $S^{* * *}$ & YES $S^{* * *}$ & YES $S^{* * *}$ & YES $^{* * *}$ & YES $^{* * *}$ \\
\hline- & YES $^{* *}$ & YES $^{* *}$ & YES** & YES $^{* * *}$ & YES $S^{* * *}$ \\
\hline YES*** & $\mathrm{YES}^{* *}$ & YES ${ }^{* * *}$ & YES ${ }^{* * *}$ & YES $^{* * *}$ & YES $S^{* * *}$ \\
\hline- & NO & - & - & - & - \\
\hline
\end{tabular}

Robust standard errors in parentheses; ${ }^{* * *} p<0.01,{ }^{* *} p<0.05,{ }^{*} p<0.1$

Note: 1 . Wald Chi-Square tests. GR = Great Recession.

2. The coefficients of BOS explanatory variables are shown only when the coefficients of interacted BOS explanatory variables are jointly significant. 


\section{Appendix E - Ordered Logit vs. General Ordered Logit}

Table E1: Ordered Logit vs. General Ordered Logit Regressions from the Business Outlook Survey - 2001Q2 to 2015Q2

Dependent variable:

Firm-Level Inflation Expectations

Ordered Generalized Ordered Logit
Logit

VARIABLES (Odds Ratio)

(1)

$(2):<1 \% \quad(3): 1 \%$ to $2 \%$

(4): $2 \%$ to $3 \%$

Past Sales Conditions: Negative

$0.838^{\star *}$

$(0.0717)$

Past Sales Conditions: Positive

Past Sales: Decline

Future Sales Outlook: Negative

Future Sales Outlook: Positive

Future Sales: Decline

Some Difficulties

Significant Difficulties

Invest in M\&E: Less

Invest in M\&E: More

Labour shortages

Number of employees: Lower

Number of employees: Higher

Wage Outlook: Negative

Wage Outlook: Positive

Input Prices Outlook: Negative

Input Prices Outlook: Positive

Input Prices: Decline

Output Prices Outlook: Negative
1.058

$(0.0779)$

0.988

$(0.0856)$

$0.852^{* *}$

$(0.0670)$

0.912

(0.0673)

1.026

(0.103)

1.068

(0.0668)

$1.289^{* *}$

(0.140)

0.960

$(0.0731)$

0.953

(0.0600)

$1.175^{\star *}$

(0.0749)

0.876

(0.0814)

1.033

(0.0634)

0.933

(0.0801)

$1.317^{\star \star *}$

(0.0870)

1.025

(0.0803)

$1.604^{* * *}$

(0.111)

$0.772^{\star \star *}$

$(0.0766)$

1.041

(0.0783)
$0.836^{* *} \quad 0.836^{* *}$

$(0.0717) \quad(0.0717)$

$1.071 \quad 1.071$

$(0.0793) \quad(0.0793)$

$0.992 \quad 0.992$

$(0.0859) \quad(0.0859)$

$0.850^{* *} \quad 0.850^{\text {** }}$

$(0.0672) \quad(0.0672)$

$0.908 \quad 0.908$

$(0.0681) \quad(0.0681)$
1.062

$1.062 \quad 1.062$

(0.103) (0.103)

1.056

(0.0664)

$1.279^{* *}$

1.056

(0.0664)

$1.279^{* *}$

$(0.142)$

$(0.142)$

$0.620^{\star * *}$

0.948

$(0.112) \quad(0.0746)$

$0.957 \quad 0.957$

(0.0619) (0.0619)

$1.166^{* *} \quad 1.166^{* *}$

(0.0751) (0.0751)

$0.861 \quad 0.861$

$\begin{array}{ll}(0.0789) & (0.0789)\end{array}$

$1.026 \quad 1.026$

$(0.0634) \quad(0.0634)$

0.963

0.963

$(0.0793) \quad(0.0793)$

$1.320^{\star \star *} \quad 1.320^{\star \star *}$

$(0.0883) \quad(0.0883)$

$0.965 \quad 0.952$

(0.200)

1.296

(0.0794)

$1.494^{\star \star *}$

(0.112)

$0.802^{* \star}$

$0.802^{\text {** }}$

(0.0762)

1.036

(0.0762)

1.036

(0.0785)

(0.0785)
$0.836^{* *}$

(0.0717)

1.071

(0.0793)

0.992

$(0.0859)$

$0.850^{* *}$

$(0.0672)$

0.908

(0.0681)

1.062

(0.103)

1.056

(0.0664)

$1.279^{\star *}$

(0.142)

1.080

(0.133)

0.957

(0.0619)

$1.166^{* *}$

(0.0751)

0.861

(0.0789)

1.026

(0.0634)

0.963

(0.0793)

$1.320^{\star * *}$

(0.0883)

$1.531^{\star \star \star}$

(0.213)

$2.293^{\star * *}$

$(0.279)$

$0.802^{* *}$

(0.0762)

1.036

(0.0785) 
Table E1 (cont'd)

\begin{tabular}{|c|c|c|c|c|}
\hline Output Prices Outlook: Positive & $\begin{array}{l}1.143^{*} \\
(0.0788)\end{array}$ & $\begin{array}{l}1.148^{* \star} \\
(0.0802)\end{array}$ & $\begin{array}{l}1.148^{* *} \\
(0.0802)\end{array}$ & $\begin{array}{l}1.148^{* *} \\
(0.0802)\end{array}$ \\
\hline Output Prices: Decline & $\begin{array}{l}0.764^{\star * *} \\
(0.0667)\end{array}$ & $\begin{array}{l}0.548^{* * *} \\
(0.107)\end{array}$ & $\begin{array}{l}0.761^{* * *} \\
(0.0678)\end{array}$ & $\begin{array}{l}1.036 \\
(0.154)\end{array}$ \\
\hline Small Firm (<100 employees) & $\begin{array}{l}1.021 \\
(0.0750)\end{array}$ & $\begin{array}{l}0.611^{* *} \\
(0.127)\end{array}$ & $\begin{array}{l}1.001 \\
(0.0771)\end{array}$ & $\begin{array}{l}1.321^{* *} \\
(0.157)\end{array}$ \\
\hline Large Firm (>=500 employees) & $\begin{array}{l}0.785^{\star * *} \\
(0.0506)\end{array}$ & $\begin{array}{l}1.262 \\
(0.281)\end{array}$ & $\begin{array}{l}0.797^{* * *} \\
(0.0570)\end{array}$ & $\begin{array}{l}0.623^{* \star *} \\
(0.0787)\end{array}$ \\
\hline Lagged Canadian Real GDP Growth (\%, q/q SAAR) & $\begin{array}{l}1.036^{* *} \\
(0.0165)\end{array}$ & $\begin{array}{l}0.898^{* * *} \\
(0.0364)\end{array}$ & $\begin{array}{l}1.027 \\
(0.0167)\end{array}$ & $\begin{array}{l}1.103^{* * *} \\
(0.0319)\end{array}$ \\
\hline Lagged Canadian Unemployment Rate (\%, SA) & $\begin{array}{l}1.000 \\
(0.0620)\end{array}$ & $\begin{array}{l}1.002 \\
(0.0626)\end{array}$ & $\begin{array}{l}1.002 \\
(0.0626)\end{array}$ & $\begin{array}{l}1.002 \\
(0.0626)\end{array}$ \\
\hline Lagged Canadian Inflation Rate (\%, 2-year avg.) & $\begin{array}{l}1.124^{*} \\
(0.0679)\end{array}$ & $\begin{array}{l}1.314 \\
(0.230)\end{array}$ & $\begin{array}{l}1.263^{\star * *} \\
(0.0820)\end{array}$ & $\begin{array}{l}0.957 \\
(0.101)\end{array}$ \\
\hline Lagged U.S. Real GDP Growth (\%, q/q SAAR) & $\begin{array}{l}1.014 \\
(0.0162)\end{array}$ & $\begin{array}{l}1.451^{* * *} \\
(0.0725)\end{array}$ & $\begin{array}{l}1.005 \\
(0.0162)\end{array}$ & $\begin{array}{l}0.838^{\star * *} \\
(0.0281)\end{array}$ \\
\hline Lagged Prime Interest Rate & $\begin{array}{l}1.485^{\star * *} \\
(0.0546)\end{array}$ & $\begin{array}{l}1.470^{* * *} \\
(0.0570)\end{array}$ & $\begin{array}{l}1.470^{* * *} \\
(0.0570)\end{array}$ & $\begin{array}{l}1.470^{\star * *} \\
(0.0570)\end{array}$ \\
\hline Lagged Growth Rate of WTI price (\%, q/q) & $\begin{array}{l}1.025^{\star \star \star} \\
(0.00244)\end{array}$ & $\begin{array}{l}1.013^{*} \\
(0.00703)\end{array}$ & $\begin{array}{l}1.020^{* \star \star} \\
(0.00247)\end{array}$ & $\begin{array}{l}1.034^{\star * \star} \\
(0.00433)\end{array}$ \\
\hline Observations & 5,376 & & 5,376 & \\
\hline Sector dummies & YES & & YES & \\
\hline Region dummies & YES & & YES & \\
\hline Quarter dummies & YES & & YES & \\
\hline Pseudo-R-squared & 0.0891 & & 0.116 & \\
\hline Model degrees of freedom & 41 & & 71 & \\
\hline Significance of model chi2 test ( $p$-value) & 0 & & 0 & \\
\hline Log pseudolikelihood & -5066 & & -4919 & \\
\hline
\end{tabular}

Robust standard errors in parentheses

${ }^{\star * *} p<0.01,{ }^{* *} p<0.05,{ }^{*} p<0.1$ 